\title{
Freedom of Contract and Occupational Licensing 1890-1910: A Legal and Social Study
}

\section{Lawrence $M$. Friedman*}

$\mathrm{T}$ HE PURPOSE of this essay is to arrive at a better understanding of judicial review of economic and social legislation during the critical period between 1890 and 1910. The United States Supreme Court and many of the state courts exercised considerable power over economic legislation during this period. In some important instances, courts evoked the concept of "due process" to strike down legislation which violated the alleged constitutional right to freedom of contract. In some instances the constitutional struggle between legislatures and courts engendered high controversy. The actions of the courts were bitterly attacked. The most bitter attacks on the judiciary came from the extreme left, but moderates and moderate progressives were on occasion equally outraged. Righteous indignation was expressed by the noted social worker and reformer, Florence Kelley, for example, who said: ${ }^{1}$

It remained for the Supreme Court of Illimois to discover that the amendment to the Constitution of the United States passed for the purpose of guaranteeing the negro from oppression has become an insuperable obstacle to the protection of women and children.

Miss Kelley's comment was specifically evoked by the decision in the 1895 case of Ritchie v. People. ${ }^{2}$ The Ritchie case, admittedly taking an extreme position, declared unconstitutional an act limiting women to an eight-hour work day and a forty-eight-liour week in "any factory or workshop." "In this country," said the court, "the legislature has no power to prevent persons who are sui juris from making their own contracts. ..." The statute was "a purely arbitrary restriction upon

* Associate Professor of Law, University of Wisconsin Law School.

1 Quoted in Hatnes, The Amertcan Doctrone of Judictat Supremacy 329 (1914). Criticism of the work of the judiciary of this period has continued. See TwIss, LawXers AND THE Constirumion (2d ed. 1962). Twiss' book is subtitled "How Laissez-Faire Came to the Supreme Court." According to Twiss, the "Iawyers and judges" transmuted into constitutional law a "theory of non-interference with self-regulating economic laws" in the interests of a "dominant minority." $I d$. at 4. Twiss' contribution to the historical tradition was to emphasize the baleful role of the lawyers among the usual nembers of the cast of villains. For a somewhat more balanced treatment, see JACOBS, LAW WRTTERS AND THE COURT (1954).

2155 Ill. 98,40 N.E. 454 (1895).

3 IIl. Laws 1893, at 99.

4155 III. at 99,40 N.E. at 455. 
the fundamental rights of the citizen to control his or her own time and faculties." Miss Kelley's sense of outrage was natural and was widely shared. It was not only the layman who demurred to the reasoning in this and like cases. One telling academic critique was Roscoe Pound's brilliant essay, "Liberty of Contract," written in $1909 .^{\circ}$ The liberty of contract cases, said Pound, were "wrong, not only in constitutional law, but from the standpoint of the common law, and even from that of a sane individuahsm." Their result was to injure the reputation of the courts themselves. "The evil of those cases will hive after them in impaired authority of the courts long after the decisions themselves are forgotten."

Of course, the courts did not lack defenders. Their own decisions were often rhetorical pieces of a high order. Wilham D. Guthrie, a leading figure in the New York Bar, voiced a sentiment widely shared by conservative lawyers and businessmen when he praised some of the very cases so criticized by progressives. "Individual liberty," he said, "should be the vital concern of every man, rich or poor. ... [L] et us be faithful and devoted to our constitutional system, which for more than a century has carried us through every storm. ... [D] isregard of the fundamental rights of others ... cannot be permitted if we are to remain a free people." In a more ecstatic vein, one writer exclaimed that,

To the mad waves of nullification, insurrection, anarchy, and socialism, [the Supreme Court] has calmly said: "Hitherto, but no farther!"; and in humbler guise it has brought and is bringing peace, security, and hope of gain, the reward of labor, for ourselves and our children. ${ }^{10}$

The controversy was not confined to cases which formally were based on the doctrine of liberty of contract. From the use of the labor injunction to the fall of the first income tax (a legal skirmish in which Guthrie himself played a major role), ${ }^{11}$ many profoundly unsettling legal develop-

5 The Ritchie case led Frederic Stimson to beheve that similar statutes would be held unconstitutional, "except possibly in New England," and where the law expressly allowed women to contract for overtime. Stmason, HaNdBook to THE LABOR LAW OF THE UNITED States 65 (1896). His prediction did not come true. In the famous case of Muller v. Oregon, 208 U.S. 412 (1908); a ten-hour law for women was sustained in sweeping terms: "[woman's] physical structure and a proper discharge of her maternal functions-having in view not merely her own health, but the well-being of the race-justify legislation to protect her from the greed as well as the passion of man."

618 Yare L.J. 454 (1909).

7 Id. at 482 .

8 Id. at 487 .

9 Gutarie, Magna Charta and Other Addresses 84-86 (1916). (1889).

10 Chamberlain, in Cooley, et al., Constirutronal History of tHe United States 285

11 The meome tax case is Pollock v. Farmers' Loan \& Trust Co., 158 U.S. 601 (1895). On Guthrie's role see Paut, Conservattve Crusis and tae Rule of Law 173, $185-86$ (1960); 
ments were not based on the Fourteenth Amendment; and, indeed, the Ritchie case itself rested heavily on an alleged discrepancy between the title of the act and its contents. The problem was not the problem of a single over-elaborated doctrine. The courts were accused of no less than writing laissez faire into the Constitution; they were accused of siding against the aspirations of the common man for social justice, of turning the constitution into an instrument of class warfare.

It is not the purpose of this Article to reexamine in detail those decisions on which the case against the judiciary rested. Our purpose is to look at a different area of legal and social history in which kindred values were at stake but no similar controversy ensued. In the same period, 1890 to 1910, occupational hicensing first achieved a firm foothold in the statute-books of most American states. Laws to license doctors, plumbers, barbers, funeral directors, nurses, electricians, horseshoers, dentists, and the practitioners of many other occupations were debated, propounded and very often passed. Many of these laws then gave rise to constitutional test cases. Unlike the more spectacular labor law cases, the licensing cases called down no pronouncements of dooin and enlisted neither proponents nor opponents in high and academic places to argue validity and propriety on the basis of first principles. This was a quieter, blander area of constitutional law. From the standpoint of logic and of life, however, the cases involved first principles no less than those which arose under wage and hour laws. If a workman had a constitutional and God-given right to contract to work eleven hours a day in a bakeshop, or to be paid in kind instead of cash, ${ }^{12}$ he should have had a similar right to contract with an unlicensed barber or to buy a laxative from a druggist without a certificate on his wall. Similarly, the right of the barber to sell his services without "paternal interference" froin the state might seem as cogent as the right of a bakery owner to buy labor umimpeded. We shall have to see, then, how the courts treated the constitutional problems raised by hicensing laws. We also shall examine wliy these licensing laws were passed, who suggested them, and for whose benefit they were enacted. A close examination of this area of legal history may provide us with a kind of control group of decisions to test our explanations of the behavior of the judges in matters of high constitutional controversy.

Lochner v. New York, ${ }^{13}$ perhaps the most famous (or infamous)

1 Swanke, The Crayate Frrar 518 (1946). The case raised a storm of criticism, and in general was so extraordinary a decision that it has been asked "how far a court is entitled to indulge in bad history and bad logic without having its good faith challenged." CoRwAN, COURT OVER CONSTITUTION 188 (1938).

12 See Stimson, Handbook to the Labor Law of the United States 101-10 (1896); Godcharles v. Wigeman, 113 Pa. 431, 6 Atl. 159 (1886).

13198 U.S. 45 (1905). 
liberty of contract case of the period, is a witness to the interconnection of occupational licensing laws and the concept of hberty of contract. Lochner arose out of a New York law regulating conditions in bakeries. ${ }^{14}$ The New York State Bureau of Labor Statistics had investigated the state's bakeshops, "their sanitary condition, lours of labor, wages paid, and the general conditions of the workmen." The investigation was undertaken in "conjunction with the Bakers and Confectioners' International Union." 16 The results were slocking. In New York City, no less than 1,049 bakeshops were located in basements, "damp, fetid and devoid of proper ventilation and hight." Some had ceilings so low the bakers were forced to "work in a stooped position." Sanitary conditions were so bad that 692 of the bakeslops were "desiguated as totally unfit to be used for food-producing purposes."17 Labor conditions were also poor. Many bakers were "obliged to work more than one hundred hours per week," in some instances "one hundred and thirty-two lours in a week . . . unmerciful hours of labor." ${ }^{18}$ New York's law attacked both the samitary problem and the labor problem. On the one hand, the law provided that "no water-closet, earth closet, privy, or ashpit shall be within, or connected directly with, the bake room of any bakery." This clause was hardly controversial. But a bolder step was taken in another part of the Act: "No employee shall be required or permitted to work in a biscuit, bread, or cake bakery or confectionery establishment more than sixty hours in any one week, or more than ten hours in any one day."

This section of the law came to grief in 1905 in a strong opinion written by Justice Peckham; the decision also evoked one of Mr. Justice Holmes' most brilliant and inspired dissents. Holmes began his dissent by remarking that the case was "decided upon an economic theory whicl a large part of the country does not entertain."19 Moreover, that theory was not a constitutional imperative: "The 14th Amendment does not enact Mr. Herbert Spencer's Social Statics." Perhaps because of the wit and pungency of Holmes' dissent, commentators have simce taken it almost as axiomatic that the majority did decide the case on the basis of an economic or social theory, in disregard of the logic of history and the facts of life. Holmes' labels have stuck.

141 N.Y. Laws 1895 , ch. 518, at 305. In 1897, this statute, somewhat modified, was reenacted as part of a comprehensive recodification of the state's labor laws, 1 N.Y. Laws 1897 , ch. 415 , at 461,485 , and it was this version that Lochner passed upon. For the general pohtical and social background of New York's reform legislation in this period, sec Hurwitz, Theodore Roosevelt and Labor Law IN New York State (1943).

1513 N.Y. Buread of Statistics of Labor AnN. Rep. vol. II, pt. III, at 5 (1896).

16 Ibid.

17 Id. at 7.

$18 I d$. at 5 .

10198 U.S. at 75. 
Justice Harlan also dissented. Justices White and Day joined Harlan but Holmes did not; nor did these three justices join in Holmes' dissent. Harlan's opinion has been largely forgotten, but it may represent a inore significant point of view. Harlan's main point was that the majority opinion was wrong on its facts. Everyone agrees, he said, that the police power "extends at least to the protection of the lives, the health, and the safety of the public against the injurious exercise by any citizen of his own rights." 20 The statute in question "was enacted in order to protect the physical well-being of those who work in bakery and confectionary estabhishments." Was there any factual basis for the legislative finding that this work was injurious to health? Yes, there was, said Harlan. $\mathrm{He}$ recounted soine of the evidence. Bakers were "pale-faced"; they had "delicate health"; they inhaled flour dust in their lungs and bronchial tubes; they were susceptible to epidemics; they worked long hours; they worked under hot, unhealthy conditions. Evidence of the foul conditions of the bakeshops was a inatter of public record, evidence to indicate, as the inayor of New York had been moved to remark, that "A bake-oven ... is the hottest and most uncomfortable place on the face of the earth." "21

Peckham's majority opinion may seem to fit the estimate made of it both by Harlan and by Holmes. It bristles with hiberty of contract language, thougll naturally Peckham recognized that the state's police power-including the power to safeguard public health-inight limit the individual's liberty of contract. ${ }^{22}$ The opinion, however, cavalierly asserts that the occupation of a baker is not "an unhealthy one to that degree which would authorize the legislature to interfere with the right to labor, and with the right of free contract on the part of the individual, either as einployer or employee." In "common understanding," the work of a baker "has never been regarded as . . . unhealthy." Any kind of labor may "possibly carry with it the seeds of unhealthiness. But are we all, on that account, at the inercy of legislative majorities?" Bankers, brokers, and bank clerks often work in buildings "into which the sun penetrates for but a short time in eacl day," and consequently these too are soinewhat unhealthy trades. If the baker's act were valid, mighit not the legislature regulate the hours of other workers too? If so, "Not only the hours of einployees, but the hours of employers could be regulated, and doctors, lawyers, scientists, all professional inen, as well as

20 Ibid.

21 Quoted in Guthrre, Magna Charta and OtHer AdDresses 58 (1916).

22 Peckham's bow to public lealth factors was probably largely in deference to the opinion of some of his colleagues. He dissented without opinion in Jacobson v. Massachusetts, 197 U.S. 11 (1905), thus indicating his disapproval of compulsory vaccination laws.

23198 U.S. at 59. 
athletes and artisans, could be forbidden to fatigue their brains and bodies ...." to preserve for the state a stock of "strong and robust" citizens. ${ }^{24}$ To Peckham, it was abundantly clear that the baker's law could not be sustained as a health measure; it was a "mere meddlesome interference with the rights of the individual," and therefore it had to be condemned.

The majority opinion in Lochner made specific mention of occupational licensing statutes. Peckham, seized by a grim foreboding, warned that "interference on the part of the legislatures of the several states with the ordinary trades and occupations of the people seems to be on the increase." He viewed this as a dangerous phenomenon, and one which sprang from the same roots as the evils of bakeshop regulation. He then cited three decisions-one from New York, one from Waslington, and one from Illinois-which invalidated statutes "regulating the trade of lorseshoeing, and requiring the person practising such trade to be examined, and to obtain a certificate from a board of examiners."25 The clear implication is that Peckham considered occupational licensing, in general, an unconstitutional and abominable interference with the rights of Americans, at least as applied to "ordinary trades and occupations."

What in fact was the attitude of the Supreme Court toward such licensing laws, as evidenced by the cases which directly raised the question? Occupational hicensing in the form which concerns us here came before the Supreme Court in 1888 in Dent v. West Virginia. ${ }^{26}$ Frank Dent was convicted of practicing medicine without a license. The West Virginia licensing statute set out certain alternative requirements for a plysician's license; one of these was that the applicant be a graduate of a "reputable medical college." Dent had a diploma from the "American Medical Eclectic College of Cincinnati, Ohio," but this did not satisfy the local board of health.

Dent's conviction was affirmed by the Supreme Court. Justice Field spoke for a unanimous bench. At the outset, he ringingly proclaimed those principles which have earned him his reputation of a stern prophet of individualism. ${ }^{27}$ Every citizen has the "right . . . to follow any lawful

24 Id. at 60 . Interestingly the occupations mentioned by Peckham, with the exception of the athlete, were precisely those which sought occupational licensing laws-professional people and artisans. Even athletes were not totally beyond the pale of legislation; bozers and boxing matches became subjects of regulation. See, e.g., Wis. Laws 1913, ch. 632, at 807, creating a state athletic commission.

25198 U.S. at 63. The cases cited are Bessette v. People, 193 Ill. 334, 62 N.E. 215 (1901); In re Aubry, 36 Wash. 308, 78 Pac. 900 (1904); People v. Beattie, 96 App. Div. 383, 89 N.Y. Supp. 193 (1904).

26129 U.S. 114 (1888).

27 The standard biography is Swisher, Stephen J. Fiedd: Craftsaran of the Law (1930). 
calling, business or profession he may choose, subject only to such restrictions as are imposed upon all persons of like age, sex and condition." 28 This right, indeed, was a "distinguishing feature of our republican institutions. Here all vocations are open to everyone on like conditions." The opportunity to practice a profession was a right which could not be taken arbitrarily from a man; it was closely allied to a property right. Nonetheless, the state has power to provide for the general welfare. The practice of medicine requires "careful preparation." It deals with "all those subtle and mysterious influences upon which lealth and life depend"; it requires "knowledge of the properties of vegetable and mineral substances," of "the human body in all its complicated parts." The state may properly limit practice to those who can give evidence of their fitness to practice. The public must be protected from incompetent doctors; yet the public can hardly judge for itself which doctors are capable and which are not. The law was consequently a valid exercise of the police power of the state. ${ }^{29}$

In Lochner Peckham did not cite Dent. Rather, as we have seen, he cited decisions upsetting the licensing of horseshoers. Presumably the distinction between the doctor and the horseshoer was that doctors were "professional" men, while horseshoers followed what Peckham chose to call an "ordinary trade," like that of the baker. Logically then, we can reconcile Peckham's opinion with the actual holdings of the Court by asserting that the Constitution forbade maximum hours laws both for "ordinary trades" and for professions (though perliaps not for extrahazardous occupations); licensing, however, was acceptable for profes-

28129 U.S. at 121.

29 The Supreme Court had subsequent opportunities to pass on the question of the licensing of physicians. Licensing laws were invariably sustained. In Hawker v. New York, 170 U.S. 189 (1898), the court upheld a statute which barred convicted felons from practicing medicine. In a doctor, said Justice Brewer, "character is as important a qualification as knowledge;" the state may ask for evidence of good character just as it may require a diploma. Harlan dissented, and Peckham and McKenna joined in the dissent. In Reetz v. Michigan, 188 U.S. 505 (1903), a Michigan law on the practice of medicine was unamimously sustained. Justice Brewer began his opinion by stating that "the power of a state to make reasonable provisions for determining the qualifications of those engaging in the practice of medicine, and punishing those who attempt to engage therein in defiance of such statutory provisions, is not open to question." Watson v. Maryland, 218 U.S. 173 (1910), concerned questions of procedural due process arising out of a conviction of a physician for practicing in Maryland without a license. Justice Day, speaking for a unanimous court, said that "it is too well settled to require discussion at this day that the police power of the states extends to the regulation of certain trades and callings, particularly those which closely concern the public health." The state courts also umiversally accepted the general proposition that statutes licensing physicians were constitutional. See People v. Phippin, 70 Mich. 6, 37 N.W. 888 (1888), upholding the Michigan statute and parading all the prior authorities into view. See also Sears, Legal Control of Medical Practice: Validity and Methods, 44 MicH. L. Rev. 689 (1946). 
sionals but not for "ordinary trades." And a "profession" seemed to be an occupational group whose activities touched subjects of public interest legitimately included in the scope of the police power. This, however, was circular reasoning. It amounted to nothing more than a statement that the police power legitimized the licensing of occupations in those cases where hicensing was legitimized by the police power. Obviously, something else is needed to explain what the courts were doing. Was it, as Holmes said in the Lochner case, an "economic theory"? To answer this question, we must take a closer look at the phenomenon of occupational licensing.

\section{$\mathrm{I}$}

OCCUPATIONAL LICENSING LAWS $1890-1910^{30}$

Even before 1890 there were many laws on the statute books which imposed a requirement of a license from the state to pursue particular occupations. The licensing of lawyers, doctors and school teachers are examples. Liquor licenses, hawkers' and peddlers' licenses, licenses to give shows and to sell patented articles were common. Many states required licenses for the selling of insurance. Some of these "licenses" were of older lineage than others. The licensing of inn-keepers and of lawyers went back to colonial times and indeed to English practice. Other types of licensing were more recent. As of 1890 the state of New York licensed a wide range of individual occupations. One group of laws regulated occupations which centered about the passenger docks of ports - steamboat operators, persons who ran boarding houses for immigrants, and that class of busy and troublesome men who solicited for boarding house and transportation concerns on the waterfront and in the streets of the cities. These laws pre-dated the Civil War. ${ }^{31}$ Physicians and lawyers were also licensed, and no unlicensed person inight act as "agent, subagent or broker in the solicitation or procurement of applications for any policy of" life insurance. ${ }^{32}$ Pawnbrokers and peddlers were

30 There is a large literature on the present status of occupational licensing laws. A critique and citations to the literature can be conveniently gathered from GELTHORN, INDTVIDUAr Freedom and Governmmentar Restratnts 105-51 (1958). State by state information is available in the volumes of the American Commonwealth Series, e.g., Garvin, The GoverNMENT AND ADMTNISTRATION OF IrtINOIS 454 (1958). There are a few studies of municipal licensing, notably Parsons, The Use of the Licensing Power bY tHe City of Cencago (1952). For Wisconsin, see Sucher, Licensing of Occulpations in Wisconsin (unpublished LL.M. thesis, University of Wisconsin Law School, 1955); Licensing by the State of Wisconsin (Research Bulletin No. 108, Wisconsin Legislative Reference Library, 1952).

311 Rev. Stat. N.Y. (1901), Emigrants, \$§ 71 ff.; N.Y. J_aws 1848, ch. 219.

322 Rev. Stat. N.Y. (1901), Ins. \& 91 ; N.Y. Laws 1884, ch. 282, N.Y. Laws 1890, ch. 401, $\S 2$. 
subject to license. Furthermore, general laws authorized municipalities to license certain specific occupations. ${ }^{33}$

In the genesis of these licensing laws, various plenomena were at work. Some licensing laws were perlıaps purely revenue-raising measures; these do not concern us here. As for the remaining licensing laws, a rougl distinction may be drawn between what we might call "hostile" and "friendly" licensing. ${ }^{34}$ The difference between the two forms can be illustrated by comparing Wisconsin's laws licensing peddlers with those licensing dentists, as both appeared in the revised statutes of 1898 . The provisions on the licensing of peddlers were quite elaborate. Wisconsin had long required or authorized the licensing of this occupation..$^{35}$ Indeed, the licensing and regulation of peddlers had colonial roots; government interference with the business of peddling could be supported by arguments of impressive hineage. ${ }^{36}$ Wisconsin had a continuing legislative interest in the peddler, and the statutory licensing provisions were enforced with some vigor on the local level. ${ }^{37}$ The statutes in 1898 required every prospective peddler to "make a written application . . . to the secretary of state," stating whether lie intended to travel on foot, by bicycle, or with "one or more horses or other beasts of burden." The peddler's license fee was graduated according to the mode of transport, from 30 dollars to 75 dollars. The "transient inerchant," lowever, had to pay 50 dollars for a license, and, in addition, fees levied by the locality in which he was to work. The statute generously limited these local fees

33 For example, the board of trustees of a village had the power to "prohibit the pursuit or exercise without a hicense, of . . . The running of public carriages, cabs, liacks, carts, drays, express wagons ... auctioneering, hawking and peddling . . . The doing of a retail business in the sale of goods of any description, from canal boats . . . . Circuses, theatres ... the keeping of billiard saloons, bowling alleys, sbooting galleries ... the giving of exhibitions." 3 Rev. Stat. N.Y. (1901), Village Law, § 90.

34 The distinction inade here is inplicit in the literature, though not always carefully spelled out. "[L] et it not be thought that occupational licensing has always or even chiefly been imposed rather than induced. Public recognition of scandalous conditions has occasionally led to licensing against the wishes of the licensees. . . . These, however, are the rarities. In the inain, those already within the occupational group clamor for licensing."

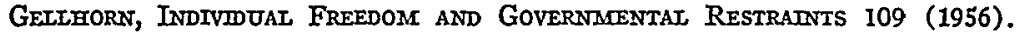

35 See, e.g., Wis. Rev. Stats. 1858, at 390.

36 See farnam, Chapters in the History of Soctal Legistation to the United STATES to $186085-88$ (1938).

37 A comprehensive new statute was passed in 1905. Wis. Laws 1905 , ch. 490 , at 858. The statutes were probably vigorously enforced in some areas. This is evidenced by the frequency with which opinions of the state attorney general dealt with legal questions arising under laws relating to peddlers, hawkers, transient inerchants, and similar pariahs. See, e.g., 1 Ops. ATr'Y GEN. WIS. 420 (1913), answering whether the proprietor of a bakery in one city who sold goods from a wagon in a different city was a peddler in the latter city. As of 1948 half of all Wisconsin cities and villages (in a survey taken of $369 \mathrm{com}$ munities) still hicensed peddlers and transient merchants. 43 THE MUNICIPALITY 92, 93 (1948). 
to no more than 50 dollars "for each day." These were stiff amountsalmost, but not quite, prohibitive. The purpose of licensing was fairly clear. It was to diminish the competition of transients and peddlers, on behalf of local sinall-town merchants. ${ }^{30}$ The licensing process was entirely in the hands of state and local officials, recruited from the regular bureaucracy. The peddlers and transient merchants themselves had no say in the hicensing process and undoubtedly had not participated in the drafting and passing of laws so harmful to their interests. This type of hicensing we may fairly call "hostile."

The hicensing of dentists can be taken as an example of "friendly" licensing. In Wisconsin, licensing was in the hands of the "state board of dental examiners." This board consisted of "five practising dentists, at least three of whom shall be members of the Wisconsin state dental society." The board was appointed by the governor. The board gave examinations but had power to dispense with the examination of "any regular graduate of an incorporated and reputable dental college." Examination fees, registration fees and license fees were moderate; the highest statutory fee was 10 dollars for an examination, one-fifth the state license fee charged a transient merchant. ${ }^{40}$

Under this statute, and despite the governor's appointment power, the dentists had wide power of self-government. ${ }^{41}$ The statute gave to

${ }^{38}$ Wis. Rev. Stat. $1898, \S \S 1571,1572.1905$ was a bad year for peddlers in Nevada, too, lest one think of Wisconsin as atypical. An act required a license for any "itinerant or unsettled merchant, trader, peddler or auctioneer ... [ [who] has no permanent store or place of business ... within the State." The transient merchant needed a separate license for every county he wanted to do business in. The hicenses were very short-term (valid one month or less), and each hicense cost the applicant $\$ 300$. Nev. Stats. 1905, ch. 153, at 260.

39 Thus the Attorney General of Wisconsin remarked in 1906 that the present act "as I personally know" was passed "with the intent that its provisions should be hberally construed in respect to vendors having a place of business," 4 WIS. ATT'Y GEN. BIENNIAL REP. 602, 605 (July 25, 1906); and that the legislature meant to exclude from the strictures of the act "local merchants having a fixed place of business." 4 W1s. ATT'Y GEN. BIENNIAL ReP. 602, 605-06 (July 25, 1906), 607 (July 30, 1906). The various attorney general opinions on the meaming and scope of the peddlers' acts were undoubtedly evoked by complaints from these "local merchants." Even "friendly" licensing reflected the lostility of the established practitioners against transients and outsiders. On the regulation of itinerant physicians by municipalities, see City of Waukon v. Fish, 124 Iowa 464, 100 N.W. 475 (1904) (ordinance applying to "All travelling or itinerant ... dentists, aurists, ocuhists, opticians and the like."); City of Cherokee v. Perkins, 118 Iowa 405, 92 N.W. 68 (1902). See also State v. Bair, 112 Iowa 466, 84 N.W. 532 (1900).

40 Wis. Rev. Stat. 1898, §§ 1410e, $1410 \mathrm{~g}, \mathrm{~h}, \mathrm{j}$.

41 Under some licensing statutes, a private association had the power to select the list of prospective appointees. In some cases, the association actually chose the members of the licensing board. There las been some litigation specifically focused on the constitutionality of this practice. In Ex parte Gerino, 143 Cal. 412, 77 Pac. 166 (1904), the board of medical examiners consisted of five members to be "elected by the Medical Society of the State of California, two members by the California State Homeopathic Medical Society, and two 
the dentists-more accurately, to the reputable, establislied and organized dentists- the power to control entry and to eliminate what they considered unfair competition. It did so by handing over the state's hicensing power to the dentists' own organization. The statute had the effect of practically putting the whole matter in the liands of the organized dentists ${ }^{42}$ since the state board was in the dentists' control. The poor peddlers liad no such good fortune.

Hostile licensing raised constitutional issues, but these were the issues raised by government regulation in general. Friendly licensing, however, was a relatively novel plenomenon which grew rapidly between 1890 and 1910. Friendly licensing legislation was almost invariably suggested and drafted by groups within the affected occupation. We lave here, then, a situation in whicll the regulated group was responsible for its own public regulation. The underlying motives for this search for regulation were clear: to rationalize the trade and eliminate "unfair competition." But every occupation seeks these goals. What made a particular occupation pursue its goals through licensing legislation? And why did the legislature pass these laws?

To answer the first of these questions we inust examine the social and economic position in which the occupations desiring legislation found theinselves. Peckhanı's Lochner opinion directed our attention to the legal status of the horseshoer, and we might begin our quest with this figure out of the past. At the turn of the century, this was a flourishing trade; the automobile liad not yet made much of an impact. Horseshoeing typically was carried on in small shops. Most master lorseshoers were individual entrepreneurs, sole proprietors, small businessmen. Most of them began their careers as journeymen horseshoers. Indeed, the Master Horseshoers' Protective Association, first organized in 1893, restricted its meniberslip to those who had worked at the trade and served the required term of apprenticeship. ${ }^{43}$ As of 1900, there were about 2,500 "journeynien" in the country, divided into "floormen" and "firemen," the latter

menubers . . . by the Eclectic Medical Society of the State of California." The act was sustained. To the same effect, see Wilkins v. State, 113 Ind. 514, 16 N.E. 192 (1888) (three members of the dental board of examiners to be appointed by the Indiana Dental Association). See Jaffe, Law Making by Private Groups, 51 HARv. L. Rev. 201, 231-33 (1937); Note, 32 Coluss. L. Rev. 80, 92 (1932). But see Munson v. City of Colorado Springs, 35 Colo. 506, 84 Pac. 683 (1906), discussed infra note 87. One nust reniember, however, that when a hicensing law has been in effect over the years, any requirement that appointees to the board be members of the occupation regulated, in practice, cedes to an association of members of the trade a good deal of control over appointments to the board, however the statute is worded.

12 See Wis. Atr'y Gen. Biennaat Rer. 114 (Sept. 13, 1910).

43 See Horack, The Horseshoers' Strike of Philadelphia, 8 Axr. J. Soc. 390 (1902).

442 Horseshoers' Magazine, p. 2 (1901). 
having higher status and pay. The International Union of Journeymen Horseshoers was organized about 1875, and by 1900 it had enlisted about one fifth of the journeymen of the country. The journeymen complained of the usual problems of the worker, hard work, long hours, excessive competition for jobs, low wages. Like all unions, the horseshoers' union wanted to organize a strong and united force in order to raise wages, to restrict entry into the trade, and to close the shops on Sundays and in the evenings.

Conflict between the Master Horseshoers and the Journeymen was not unknown. A bitter strike occurred, for example, in Philadelphia in $1902 . .^{45}$ But there were examples of fraternalism between masters and men, even on the social level, which hardly accord with the conventional picture of a class struggle. On August 22, 1901, for example, an "annual outing and picmic of the Chicago Horseshoers," at "beautiful Cedar Lake in Indiana," was jointly sponsored by Masters' Local No. 5 and Journeymen's Local No. 4. Masters and men alike took part in the pie eating contest, the broad jump, and the races; and masters and men alike competed for prizes of cigars, silver spoons and gold cuff buttons. Such outings, said the corresponding secretary of Local No. 4, could only be "productive of great good and will surely result in drawing the masters and journeymen closer together in bonds of friendship and good feeling." And "why not?" he asked; "master to-day, journeyman tomorrow, and journeyman to-day, master tomorrow." 46 Earlier that year masters, men, and implement salesmen enjoyed a common smoker. The company was regaled with a mandolin and guitar solo; John Kane recited "The Village Smithy," and Professor John Hone imitated the strongman Sandow, bending iron bars "on his bare neck." There were prize fights, Irish jigs, and a flute and viohin solo, not to mention the usual speeches. The smoker closed with an "elegant and much appreciated refreshment and luncl.." In all the merriment and speechmaking we can detect a persistent theme: the unity of interest and aims of masters and men. ${ }^{47}$

It is worth leafing through these faded daguerreotypes because the passion for licensing was intimately related to the social and economic position of the occupation to be licensed. Conditions in the blacksmith trade made possible picnics and smokers witl the bosses on terms unthimkable in the meat-packing plants and steel mills. The distinction between master and man in this trade was narrow. The "bosses" were typically former journeymen, and as masters, they remained in close daily contact with their men. More important, master and man shared

45 See generally Horack, supra note 43.

462 Horseshoers' Magazine, p. 1-3 (1901).

472 Horseshoers' Magazine, p. 6 (1901). 
common problems. One such problem was caused by the ease of entry into the occupation. Large amounts of capital were not necessary to open up a shop; long professional training was not necessary to prepare a man for the job of floorman in a shop. Any regulation of the supply of horseshoers would tend to benefit both groups. Licensing ideally would ehminate at the same time scab workmen and fly-by-night, cut-rate shops. The business was highly competitive. Perhaps both masters and men were anxious to close their doors on Sunday, but the niaster could not do so unless his conpetitors did likewise, and the journeyman's union could not close down the one-man shops and the scab shops without cooperation from all the masters.

It is easy to see, too, that a move to hicense horseshoers would have engendered relatively little public controversy even if the bosses had protested. The employers, as a group, had almost as little economic and pohtical power as the employees. Nobody could imagine a legislature dominated either by the horseshoers (as such) or their employers (as such). Both capital and labor here were small, diffuse and marginal. But a legislative program acceptable to both employer and employee was possible, and little public opposition could be expected. For a variety of economic reasons, hicensing laws and Sunday closing laws would tend to benefit master and man abike.

State hicensing of barbers also began in the last decade of the nineteenth century. The problems of the barbers closely paralleled those of the horseshoers. Here, too, the journeymen barbers' union played an active role in the licensing movement. Boss barbers were small businessmen with few employees. Many barbers were sole practitioners, occupying a curious half-way status between "bosses" and employees. ${ }^{48}$ In many cities the employing barbers organized their own protective organizations. The barbers' umions worked hard for Sunday closing laws, for public acceptance of unionized shops, and for hicensing laws to eliminate "cutthroat" competition. A special problem of the barbers was the "quickie" barber school. At a banquet in 1901, S. J. Errington, of Local 14 of the Barbers' Union in Fort Wayne, Indiana, complained indignantly of eightweek courses, which turned out hosts of new barbers to start their own shops and "cut prices." These were the men, he said, who were "unable to tell the difference between a filthy disease and a pimple."49

The pages of the barbers' union journal do not reveal the kind of chumminess between master and man that reigned among Chicago horseshoers; indeed, there was mucl blatant hostility. ${ }^{50}$ But it requires

48 See 6 Journeyman Barb., p. 102-05 (1910).

4912 Barbers' Journat 34 (1901).

$50 \mathrm{It}$ is hard to tell how general this hostility was. For cooperation between the master 
little imagination to see that cut-rate, quick-trained barbers were a threat both to employer and employee. The man who started a shop and charged less than "fair" rates hurt the one as much as the other. To S. J. Errington the remedy was clear: lie was a violent partisan of licensing laws. "It takes legislation," he said, "to protect us from scab prices, pestilence, and disease." $" 151$

Some licensing laws were drafted by the journeymen barbers; sometimes master barbers prepared their own versions. The legislative struggle sometimes hinged as much on which licensing plan to adopt as whether to adopt one at all. In the licensing of barber and lorseshoer, enacted law was often a compromise, with both "master" and "journeyman" groups represented on the licensing boards. The licensing law of Washington state, passed after a "hard struggle" led by the Seattle, Spokane, and Tacoma journeymen's unions, set up a three-man board, two union members and one "boss barber." The balance was sometines the other way. Thus, Michigan's horseshoer act of 1899 set up a five-man board with "one veterinary surgeon, two master lorseshoers and two journeymen horseshoers."

The barbers' and horseshoers' laws were for the benefit of unionized occupations, but the employers were weak, small businessmen, and there was considerable mobility between the employee and employer class. The success of the licensing movement depended in part on the absence of a strong and coherent pressure group of employers united in opposition to licensing. The same point can be made about the health professions, doctors, dentists, pharmacists, optometrists, osteopaths, veterinaries, nurses, midwives. Alınost all of these groups were troubled by "competition." Since they were in the main self-employed, they simply constituted an a fortiori case of the same phenomenon which gave rise to the licensing movement among barbers and horseshoers. One group, the pharmacists, was made up of both employers and einployees. In some ways druggists shared more problems with blacksmiths than with doctors. ${ }^{54}$

and journeymen barbers in Los Angeles following passage of a state licensing law, see Stmison, Rise of the Labor Movearent in Los ANigeies 239 (1955). Perhaps the "harmony" extended to pre-licensing days as well.

5112 BARBERs' JouRnal 34 (1901).

52 Id. at $82-83$.

532 Howells Ann. St. Mich. 1913, §5222 (Act No. 229, 1899, § 2).

54 For example, the problem of one-man shops and ease of entry into the business. The Committee on Trade Interests of the Illinois Pbarmaceutical Association complained in 1905 that "The young man who succeeds in passing the Board of Pharmacy exam, and secures a certificate . . . is never satisfied until he either saves or borrows a few hundred dollars, and with the help of a friendly wholesaler, starts in business for himself. Without adequate means to conduct his business properly, he is driven to do almost anything to eke 
Undertakers, embalmers, and funeral directors were another smallbusiness group that lieard the siren-song of the licensing movement. This occupation suffered from all the ills which gave rise to the urge to be licensed. Partly because of the nature of their trade, these men badly needed professional prestige. At about the turn of the century the undertakers-they were not yet called "morticians"-were struggling to define and protect an area of exclusive business competence. They faced many rivals. Doctors as well as undertakers embalmed the dead. Clergymen asserted ancient and respected claims to control over ceremonial aspects of burial. Most of the country's undertakers were part-time funeral directors, whose major business was the sale of coffins and caskets. A model legislative act for licensing embalmers was prepared in the late 1880's by Hudson Samson, president of the Funeral Directors' National Association of the United States. Samson, an unsung liero of American social life, pioneered in joiming the role of embalmer with funeral directing and led the movement to take control of embalming away from the medical profession. Samson also exerted heroic efforts in designing the artifacts of the professional funeral. In 1889 he designed a "special eight poster, oval-decked funeral car," and in 1898 he created his masterpiece, a magnificent hand-carved wooden drape hearse. As president of the Association, he raised his voice in favor of "professionalizing" the undertakers. Licensing was an essential step. Samson demanded passage of a law "regulating the care and burial of the dead the same as there is for the practice of medicine." Virginia obliged him in 1894, and by 1900 some twenty-four states had enacted legislation. The Virginia law set up a board of five members, appointed by the governor; each member must have had at least "five years' experience in the practice of embalming and the care of and disposition of dead human bodies." Only registered embalmers could thenceforward practice "the science of embalming."

The difficulties of the funeral directors in competing with doctors, clergymen, and casket-salesmen point up a problem central to the status of the "professions," the difficulty of defining an area of exclusive coinpetence. An occupation cannot qualify as a "profession" without successfully pressing such a claim. Lawyers, for example, have waged an un-

out his existence." One member agreed wholeheartedly: "Some provisions should be made so that upon passing the examination as a registered pharmacist [an assistant] cannot immediately start a drug store. (Applause.) This business of making it easy for young men to pass an examination and immediately start in business is what is hurting us." Proceedings 26th Ann. Meeting IIl. Pharmaceutical Ass'n 42, 47 (1905). These complaints were voiced after licensing had been achieved in Illinois; the druggists now wanted even tighter control to eliminate "unfair" competition.

$55 \mathrm{Va}$. Assem. Acts $1893-4$, ch. 625, at 727, 729. The material in the text on this "pro-

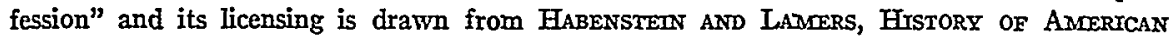
Funerax DiRecting 365, 369, 457-501 (1955). 
ceasing struggle against "unauthorized practice," a struggle not only against uneducated and imposter lawyers but also against educated laymen-accountants, brokers, trust officers-whose skills, training, and work experience overlap that of the lawyers. Another occupation with a serious problem of unauthorized practice was the real estate broker, whose own drive for licensing won its first success in California in 1917.60 Not only did the real estate broker face the problem of defining an area of exclusive jurisdiction, he also faced the problem of eliminating competition from marginal, part-time brokers, including persons who sold a house or two from time to time, and who were simply looking for a few fast dollars. It required no great skill to dabble in real estate, in any event no "professional" skill. Real estate speculation had been a great American pastime for generations. Land law and real estate forms had been simplified to the point where a literate adult might easily try his hand at buying and selling a parcel or two. Everybody with a nose for real estate fancied limself in the business. Very little if any capital was required-no office, no secretaries, no overhead. An examination of Wisconsin cases during the period 1905 to 1915 in which brokers sued for their commissions underscores these facts. Most of these "brokers" were marginal and part-time dealers in land; many of them kept no books, had no offices, and drifted in and out of the business. They had no fixed commission rates; obviously their activities interfered with the more "professional" brokers who wished to maintain the price line and regularize their business practices. ${ }^{57}$ In many ways, the brokers were as badly off as the barbers. And like the undertakers, the brokers felt a need for the prestige of professional status. Licensing was necessary to rid them not only of the marginal brokers, but also of the onus of the "land sliarks."

${ }^{56}$ Theobald, Real Estate License Laws in Theory and Practice, 7 J. LAND AND Pub. UtIIIIIES Econ. 13 (1931); Cal. Stats. 1917, ch. 758, at 1579. The act licensed brokers and real estate salesmen; licensing power was in the lands of a state real estate commissioner. Neither the commissioner nor his clerks or deputies could legally be "interested in any real estate company, or real estate broker, as director, stockholder, officer, member, agent or employee." In this respect, the California act deviated from the typical pattern of the "friendly" licensing law. More standard was, for example, Fla. Laws (Extraordinary Sess. 1925) ch. 11336, at 1, which created "The Florida Real Estate Commission . . . to consist of three persons, to be appointed by the Governor, whose vocation for at least ten years prior to their appointment has been that of a real estate broker." Successful passage of real estate license laws followed a period in which many abortive attempts were made to procure such laws. See, e.g., 1911 Wis. Assembly Bills, No. 907A; N.Y. Times, March 12, 1916.

57 See, e.g., Zitske v. Grohn, 128 Wis. 159, 107 N.W. 20 (1906). Zitske, suing for a coinmission, was a "broker" who had no office. As to variations in brokerage rates, see Burdon v. Briquelet, 125 Wis. 341, 104 N.W. 83 (1905).

58 John A. McCormick, a Milwaukee dealer, speaking in favor of a licensing for 
II

THE ASSOCIATIONAI MOVEMENT

It has been sufficiently demonstrated how much the licensing urge flowed from the needs of the licensed occupations. The state did not impose "friendly" licensing; rather, this licensing was actively sought by the regulated. Typically, however, the moving force was the influential, orgamized segment of the occupation, a trade group. This group or association was sometimes a labor union (as in the case of the Journeymen Barbers), sometimes an employing group (thouglı in these cases employer groups were almost "unions" in their own riglit), sometimes a trade association (for example, the funeral directors, and the various real estate boards), sometimes professional groups (for example, medical and dental societies, and bar associations). Licensing was an attempt to enforce, through legal mechanisms, goals which a trade or professional association was unable to carry through completely on its own.

The association movement is, therefore, one of the critical social phenomena underlying the rise of occupational licensing at the end of the nineteenth century. But the siguificance of the movement did not exhaust itself in creating the forces which ended in these relatively obscure statutes. Many scholars have sensed in the post-Civil War "associative current" a symptom of a far-reaching social change which affected every area of American life. ${ }^{59} \mathrm{~A}$ relatively atomistic, individualistic economic and social order was replaced by a social order characterized by the formation of many contending economic and social interest groups. Perhaps the individualism of pre-Civil War American life has been grossly exaggerated. The archetypical individualist was the frontiersman-a member of a small minority, whether he measured up to his inyth or not. But whatever was the nature of the immediate past, it is true that late nineteenth-century hife was fertile soil for the creation of associations, particularly economic ones. ${ }^{60}$ For our purposes, we will mention four kinds: first, "trusts" and other associations of industrial

brokers, stated that brokers wanted such a law because "we do not wish longer to be called land sharks." Milwaukee Journal, Feb. 16, 1917.

59 See Schlesinger, Biography of a Nation of Joiners, 50 Am. Hist. REv. 1, 16-19 (1944). For a recent and provocative perspective on the role of voluntary organizations in nineteenth century social hife, see Thernstrom, Poverty and Progress: Social MobIfITY in a NIneteenth Centurx City 167-71 (1964).

BO For example, the frontier claims clubs, composed of claimants to public lands, were long looked upon as examples of "pioneer democracy." Recent research, however, has emphasized quite different features of their activities, features aimed at limiting access of "outsiders" to claims to public lands and at holding down the prices at which such lands might be offered to settlers by the Federal Government. See Bogue, The Iowa Claim Clubs: Symbol and Substance, 45 Muss. VArter Hist. Rev. 231 (1958); Friedman, The Usury Laws of Wisconsin: A Study in Legal and Social History, 1963 WIs. L. Rev. 515, 530-32. 
firms, loosely or tightly organized, including trade associations; second, labor unions; third, associations of occupations and small businesses (for example, retail druggists associations, the master barbers, bar associations); fourth, farmers' organizations, including the state granges, the American Society of Equity, and farmers' cooperatives. Established associations which were successful in achieving economic goals naturally drew in the uncommitted; as Emile Durkheim, the French sociologist, has remarked, "a collective force draws into its orbit those who are unattached: any who remain outside are unable to hold their ground." Competitors were forced either to join or to form rival associations to do battle on more equal terms.

The associational impulse was probably grounded in psychological as well as economic needs. Moreover, the great burst of nineteenth century associations was a response to new technology as well. Had he decided to form economic associations, the hypothetical frontier individualist could not have done so without suitable means of transport and communication. Transport and comunication advances made possible mail-order houses, swifter traveling salesmen, and national advertisingnew dangers for the retail druggist, already battling peddlers and transient merchants. But mass transport and communication also gave the druggist the opportunity to group himself with other druggists who faced the same problems. Similarly, a steel trust was unthinkable without a well-knit railroad net. The railroad created the western farmer who fought the railroads through his associations. The association movement flowered alongside of the technology that made it possible.

Occupational associations take as their goal the task of defining an area of exclusive economic jurisdiction and protecting that area against competition. An agreement among producers to carve up the country into exclusive geographical regions and parcel these out among existing firms is a clear example of associational restraint of trade. Unions have also been eager to define their jurisdictions, either in terms of location (by orgamizing a whole plant or a whole city) or in terms of task (as by insisting that all carpentry work within a plant must be done by the carpenters' union). Farmers' organizations have often attempted to assert exclusive jurisdiction over segments of the marketing chain which "belong" by rights to the farmers. Occupational licensing is a technique for creating an occupational monopoly; all unlicensed practitioners are excluded both from the group and from the occupation.

61 Durkabtor, Professtonat Ethics and Civic Morats 39 (1958). For an interesting analysis of the internal characteristics of private economic associations with particular emphasis on labor unions, see McConnell, The Spirit of Private Government, 52 AM. PoL. Scr. REv. 754 (1958). 
Each occupational association thus sought to claim territory and hold that territory agaimst competitors, choosing methods of economic warfare appropriate to the occupation and to the type of association. Doctors could hardly have formed a labor union; they had to preserve their professional status, and if possible, enhance it, which required rejection of the associational forms of workmen. Besides, doctors had no employers to strike against. The doctors had to insist that they were a learned, technical, elite occupation, a profession. ${ }^{62}$ And by the same token they had the right to exclude those who did not measure up to their standard. Strong medical societies and mandatory hicensing laws proved to be appropriate and effective tools of economic warfare. The working barbers were unionized, but standard union tactics were ineffective weapons against the unorganized, and against the employers, who constituted a diffuse, shifting group. Licensing was a sounder tool; the state could fill in gaps left where private action failed. Licensing was also valuable to the einploying barbers, to curb errant fellow-employers and eliminate oversupply on the employing side. The industrial giants could not join unions, but they could merge, form trade associations, and enter into contracts and trust arrangements to enforce their economic claims among themselves and against workmen and competitors. Farmers' orgamzations experimented with cooperatives ${ }^{63}$ and with control over marketing of agricultural products. The union proved to be an appropriate device for mobilizing masses of workers. The licensing of industrial workers was a possible supplementary technique, but rarely attempted. Illinois hicensed coal miners in $1908,{ }^{64}$ and a Pennsylvama law of 1907

62 This essay avoids, in general, the use of the term "profession" as an expression for a discrete category of occupations. One leading sociological view of what a profession is lays heavy stress on "intellectual technique . . . to be acquired only by specialized intellectual training." Carr-Saunders and Wilson, Professions, 12 ENCYC. Soc. Scr. 476, 479. See also Greenwood, Attributes of a Profession, 2 Soc. Work 45 (1957), Barber, Some Problears In the Sociology of the Professtons, 669, 672 (1963). This essay deals with occupations which have sought (and sometimes achieved) prestige and economic exclusivity through the use of social controls, chiefly friendly licensing. Once this is done, "intellectual technique" and "training" can be invented and enforced as a "prerequisite" at the will of the leaders of the occupational group. One may, if one wishes, refer to occupations which have reached this stage as "professions." An excellent case study analysis of the politics and sociology of a licensing struggle which sheds great light on the meaning of the term "profession," is Goode, Encroachment, Charlatanism, and the Emerging Profession: Psychology, Sociology, and Medicine, 25 Axr. Socrococy Rev. 902 (1960).

63 "The co-operative nrovement in agriculture simply represents an attempt of business organization in a small-scale industry to achieve for its meinbers some of the advantages that the large corporation, the so-called trust, and the trade association have achieved in other commercial fields." Nourse, THe Legad Status of Agricultural Co-operation 19 (1928). On the development and status of agricultural co-operatives in the early 20th century, see Hanna, THe Law of Cooperative Marketing Associations (1931).

64 Ill. Laws 1908, at 90 . The act was "to provide for the safety of [miners] . . . and 
declared that no one might be employed in "the anthracite coal region of this commonwealth in any anthracite coal mine, without having obtained a certificate of competency and qualification so to do from the 'miners' examining board' of the proper district." Each such "board" consisted of "miners ... appointed, from among the most skillful miners actually engaged in said-business ... and who ... have had five years practical experience." Unquestionably, the United Mine Workers were behind this act, contemporary with a bitter struggle to organize the anthracite mines of Pennsylvania. ${ }^{65}$

In general, however, licensing seems not to have been used much as a method of achieving a statutory closed shop. The unions, to be sure,

to prevent the employment of incompetent persons as miners," and set up countywide "Miners' Examining Boards" each to "consist of three miners who shall be appointed by the circuit judges of the judicial district in which such county shall lie." The members were to be "experienced and skillful miners actually engaged in said business in their respective districts." To qualify for a certificate, the prospective miner had to sbow "not less than two years of practical experience as a miner or with a miner," and each candidate had to answer "twelve practical questions" on the subject of mining. Without a certificate, no one was allowed to "practice." James H. Matheny, president of the Illinois Bar Association, sneered at the act, since it required "examination of coal miners so that a coal miner, like a lawyer, must obtain a certificate of competency." 32 Proc. Irt. ST. BAR Ass'N ANN. MeEtro pt. II, at 6 (1908). Perhaps he resented the analogy. A prior act, Ill. Laws 1897, at 189 , required "every person desiring to work by himsclf in rooms of coal mines in this State" to produce "satisfactory evidence to the mine manager ... that he has worked at least two years with or as a practical miner." Without such cvidence, "he shall not be allowed to mine coal, unless accompanied by some competent coal miner, until he becomes duly qualified." See Grock, John MrtchenL-Miner 26 (1929), on the role played by the mine workers' umion with respect to the 1897 law.

65 For the act, see 3 Purdon's Dig. Stats. Pa. 2562 (13th ed., 1907). In Commonivealth v. Shaleen, $215 \mathrm{~Pa}$. 595, 64 Atl. 797 (1906), a conviction under the act was upheld; "Jolnn R. Jones for the United Mine Workers of America" was listed as one of the attorneys arguing the prosecution side; for background, see DUITES, LABOR IN AMIERTCA 188-93 (1949).

After the great Pullman strike, a suggestion was made by a member of the General Managers' Association (representing officials of the railroads which terminated in Chicago) that railroad employees be hicensed as a means of controlling railroad labor. LINDSEY, THE Putiman Struke 352-53 (1942). Subsequently we find, for example, an Alabama statute which made it the "duty of every person or corporation operating a railroad in this state, before employing any person as train dispatcher, engineer, conductor, fireman, flagman, brakeman, trackman, or switchman, to subject the applicant for employment to a thorough examination respecting his capacity to fill the position applied for, his knowledge of the rules and regulations governing the employees of the railroad, the knowledge which may be necessary or proper for the skillful performance of his duties, and shall subject the applicant for employment to a thorough examination respecting his ability and capacity to see and distinguish objects and color, commonly called color-blind examination, and respecting his sense of hearing." 2 Ala. Code 1907, § 5481, at 1245-6. This was "hostile" licensing but handed over to a private power-group for enforcement, and the public interest in trainmen who could see and hear properly was both obvious and persuasive. The statute illustrates other possible uses of the licensing technique in the context of associational struggles-uses which, in the main, never bore fruit. 
did not neglect the possibilities of legislative aid in securing their economic ends. But the opposition, the major employers, was powerful. Unions won legal victories piecemeal, item by item-battles against company stores, convict and child labor, Sunday closing laws, eight-hour and ten-hour laws-im one, many, or most jurisdictions. Licensing was associated with trades of greater skill or prestige. Union-controlled licensing would have evoked stubborn and passionate resistance. Closedshop agreements, a functional equivalent of licensing, were not readily inposed on employers, at least not until a later generation. It is worth mentioning, however, that the Clayton Act, a statute directed against illegal combinations of businessmen, specifically exempted associations of workmen (and farmers) from its strictures. ${ }^{66}$

Each type of associational activity raised some possible question of restraint of trade, and insofar as an occupational group sought to enforce its claims of exclusive jurisdiction through legislation, questions of freedoin of contract under the Fourteenth Amendment were raised, at least in theory. The economic struggle which lay behind the association movement was the occasion for a vast outpouring of legislation in the late mineteenth century, legislation passed either to curb association, as in the case of the Slierinan Act, or to encourage it, as in the case of occupational licensing. There was no single legislative response based on a single, consistent theory of the proper relationship of the state to the economic order. There were many responses. Legislatures distinguished between occupations, between situations, between types of statute, between various economic interests. The "trusts" were attacked, however ineffectively, by the Sherman Act and by a great range of state statutes. These statutes reflected the widely-held opinion that the nassed power of the great corporations threatened the social and political structure of the country, as well as its economic structure. Business association was not to be guided simply on the basis of the principle of freedom of contract, since unfettered freedom of contract led to the amalgamation of excess power, the "curse of bigness." So moderate and conservative a scholar as Frederic Stimson cried out in alarm, in 1887, that "we are confronted with a new monster a thousand times more terrible" than the old corporation, a "legal machine which may swallow a hundred corporations of a hundred thousand individuals; and then, with all the corporate irresponsibility, their united power be stored, like a dynamo,

$66 \S 6$ of the Clayton Act, 38 Stat. 730 (1914), 15 U.S.C. $\$ 17$ (1958), declared that "the labor of a human being is not a commodity or article of commerce. Nothing contained in the antitrust laws shall be construed to forbid the existence and operation of labor, agricultural or horticultural organizations, instituted for the purposes of mutual help, and not ... conducted for profit." 
in portable compass, and wielded by one or two men." ${ }^{\prime 77}$ On the other hand, regulation of public utilities took the form of a kind of licensing, the franchise. Regulated companies were granted exclusive jurisdictions and protected against economic loss through the guaranty of a "fair" rate of return on their capital. Utility licensing was formally "hostile," but this meant in practice only that the ultimate bargain between state and utility was less favorable to the utility than the bargain between the barbers and the legislature. Not every occupation could have its own way as completely as the druggists of Kentucky. The President of the Kentucky Pharmaceutical Association reported in 1898 that "we were successful in having [our] bill become law in almost the exact form mapped out by the Association at the Crittenden Springs meeting. ${ }^{308}$ Public utility regulation often grew out of an atmosphere of hostility. Statutes were passed to curb the power of the unregulated utilities. Statutory commissions, however, frequently adopted a friendlier attitude toward their regulated companies than the public evisioned, either out of conviction, venality, or necessity. A kind of friendly licensing could thus result even where the governing board was not formally recruited from the industry. ${ }^{69}$ Friendly and hostile licensing, indeed, were ideal types; in practice, legislation and practice demonstrated a series of subtle gradations in between.

The legislative response to the aspirations of organized labor was particularly complex. But there were scores of statutes passed at the instance of organized labor in general or of particular unions. Even more were proposed but failed, and others perhaps were never proposed by reason of suspected futility. Of the statutes which were enacted, enough were declared unconstitutional on one ground or another to lend some plausibility to the theory that the judiciary was hostile to organized labor. The rise of the labor injunction did nothing to dispel this theory. In the legislature, "union legislation" had the greatest chance of passage when it could mobilize on its behalf the support of the vast, uncommitted middle classes, or more importantly, the

67 Stimson, Trusts, 1 Harv. L. Rev. 132 (1887). For a succinct account of the state of public, economic, and legal opmion on the trust question, see Letwin, Congress and the Sherman Antitrust Law: 1887-1900, 23 U. CHr. L. REv. 221 (1955).

6821 Proc. Ann. Meeting Ky. Pharacaceuttcal Ass'n 27 (1898).

69 Conversely, pure "regulation" could be vested entirely in the hands of representatives of the regulated. Thus, in Nevada an act of 1907 created a State Board of Sheep Commissioners, with wide power over the control of diseased sheep, including the power to order all sheep to be dipped in a "lime and sulphur, or a sulphur and tobacco dip." The Board "shall consist of three members, all of whom shall be experienced wool growers." Nev. Stats. 1907, ch. 120, at 234. In a 1909 Wyoming act of similar import, each board member had to be "a qualified elector of the county from which be is chosen, and an owner of sheep within the State." Wyo. Laws 1909, ch. 60, at 96. 
social workers, reformers and humanitarians who represented the conscience of the middle classes and most of the rich. Some reform movements were particularly successful-the legal war against child labor, for example. The unions strongly favored the elimination of child labor, and the women's clubs and the middle class reformers entered the struggle on humanitarian grounds. ${ }^{70}$ Similarly, tenement house laws and pure food acts were passed because wide public support could be mobilized on their behalf. Indeed, in Wisconsin the first Tenement House Law (1907) was the creature of state civil servants with a zeal for housing reform. The leading LaFollette Progressives, the Social Democrats, and the building trades were profoundly indifferent to the proposal. ${ }^{71}$ The more famous New York tenement house law of 1901 owed its legislative success ehiefly to two nien, Jacob Riis, who revealed to a scandalized world how the "other half" lived, and Lawrence Veiller, who channeled the aroused public opinion into a practical form and lobbied his bill through the legislature. ${ }^{2}$

The Pure Food and Drug Act of 1906 has hikewise two heroes; Dr. Harvey Wiley was its Veiller, and its Jacob Riis was Upton Sinclair. The passage of the act was practically assured when Sinclair wrote The Jungle, and explained to a nauseated public how workmen who fell into the cooking room vats might be "overlooked for days, till all but the bones of them had gone out to the world as Durham's Pure Leaf Lard."'73 Sinclair himself had Socialist leanings. His novel was written to attract sympathy for the workmen who turned into lard, but the public was niore interested in the adulterated lard than in the workmen who adulterated it. Sinclair said: "I aimed at the heart . . . and hit . . . the stomach." ${ }^{\prime \prime 4}$ Apparently, it was possible to mobilize independent public

70 Comamons \& Andrews, Principles of Labor Legistation 244 (Rev. ed. 1927), remarked that "men workers undoubtedly believed that restrictions on the hours of women and children would result in decreased employment of these classes of wage-earners, with consequent advantages to themselves." Jane Addams tells how she became aware of the child labor problem during her first Christmas at Hull House. She offered candy to some children, only to find they worked in a candy factory long hard hours and "could not bear the sight of it." Soon she encountered "incredibly small children" hard at work in the sweatshops. At that time "the only child-labor law in nlinois with any provision for enforcement had been secured by the coal miners' unions, and was confined to children employed in mines." With the aid of Florence Kelley, interested persons began the task of mobilizing public opinion and gathering reliable labor statistics. It was necessary to "appeal to all elements of the community," but the "trades-unions" rendered "the most energetic help." Addasss, Twenty Years at HuLI House 148-50 (1960).

71 Wis. Laws 1907, ch. 269. See Friedman \& Spector, Tenement House Legislation in Wisconsin: Reform and Reaction, 9 Aar. J. Legar HIst. 41 (1965).

72 See Lubove, the Progressives aNd the Slums (1962).

73 Stnctair, The Jungle 102 (1960). On Wiley's role, see Anderson, The Health of a NATION (1958).

74 SINCLAIR, op. cit. supra note 73 , at 349. 
support for pure food laws but not for the broader labor programs Sinclair had in mind. The evidence suggests that in the Progressive period, success in "reforming" depended on mixing motives and mobilizing diverse interest groups. The barbers of Philadelphia collected 1500 dollars from "wealthy and philanthropic" members of Sabbath observance societies to help them in their struggle to close down barber shops on Sunday. ${ }^{75}$ The success of the Sunday closing movement, in many branches of industry and trade, depended on enlisting those who were interested in the Lord's work along with those who were interested in the union's.

We have analyzed, at least in general terms, the origin of the licensing movement and the general associational drive im the late nineteenth century, and we have said a few words about some factors which influenced success and failure in the pursuit of legislative goals. Occupational licensing won many successes. ${ }^{76}$ By 1910 in Wisconsin, for example, doctors, veterinaries, pliarnacists, midwives, nurses, embalmers and barbers had all achieved some form of licensing. Wisconsin had experimented, too, with plumbers' licensing; many states regulated this occupation. Other "professions" were hicensed in scattered jurisdictions. Some of these trades were soon to extend their licensing statutes throughout the land. New Jersey in 1902 passed an "Act to regulate the practice of architecture"; no one might thereafter practice as an arclitect in New Jersey without a certificate from the "New Jersey state board of architects," a body of five men "at least four of whom shall be, at the time of ... appointment, architects residing in the state of New Jersey, and who have been engaged in the practice of their profession for at least ten years."77 Engineers and real estate brokers were waiting in the wings for their chance on the licensing stage. The licensing movement had within it wide generative power. But despite legislative success, much depended on the judicial view of constitutional law. Doctrines of constitutional law surely played a part in the legislative arena; many hicensing bills may not have been proposed, or, if proposed, were defeated because of legislative perceptions of the character of constitutional doctrine. This is, however, an imponderable. More palpable is the record of litigation. Many licensing laws were challenged in the courts, and some did not survive the challenge. To this we now turn.

7512 Barbers' Journat 5 (1901).

${ }^{76}$ There were as many failures as successes, however. For example, a bill was introduced into the Wisconsin assembly in 1907, to license master electricians; the proposed licensing board consisted of one electrical engineer, one master electrician, and one municipal electrical inspector, a fairly nice balance. 1907 Wis. Assem. Bills, No. 562A. The bill failed. 1907 Wis. Assem. J. 707, 1673. See also note 56 supra.

it N.J. Acts 1902, ch. 29, at 54. 


\section{III}

\section{OCCUPATIONAI IICENSING IN THE COURTS 1890-1910}

The United States Supreme Court did not frequently have occasion to deal with occupational licensing. The only line of cases of any substantial importance dealt with the licensing of physicians. That line uniformly sustained state licensing laws. Lochner cited three state court cases overturning horseshoers' license statutes, but Peckham could find no authority in his own court which held a "friendly" licensing act unconstitutional. This, then, is an important though negative point. In the critical period of the development of trade restriction through licensing, the United States Supreme Court did not build up a guiding body of constitutional doctrine. ${ }^{78}$

The state courts generated substantial case-law, however. Yet, it must be borne in mind that constitutional litigation was never systematic. A quantitative study would undoubtedly show that the majority of occupational licensing laws and ordinances were not challenged during this period. Cliallenges sometimes came many years after imitial passage of an act, and were sometimes directed against only one aspect of the statute attacked. Freedom of occupational choice lacked champions even on the state court level.

It is rare for a person to challenge a statute on purely ideological grounds, even aside from questions of standing to sue. Usually, a constitutional issue is raised by someone who suffers economic harm from a statute. Either his livelihood has been threatened, or he faces criminal prosecution for failure to comply witl the statute (or because of his "unauthorized" and unlicensed practice). Litigation is not cheap; it is not a customary weapon of persons of limited means and himited social status. Consequently, in occupational licensing cases the constitutional issue was usually raised by individuals of some social status, with some professional standing in the commumity. ${ }^{79}$ The nature of licensing laws was such that licensing tended to enlist all the reputable practitioners practising at the date of passage of the licensing statute. Indeed, the statutes were usually explicitly lenient toward old hands in the field.

78 The court decided many cases of hostile licensing, however, including such famous cases as Yick Wo v. Hopkins, 118 U.S. 356 (1886), and the Slaughterhouse Cases, 83 U.S. (16 Wall.) 36 (1872). And the Supreme Court frequently asserted the constitutional right of a citizen "to earn his hvelihood by any lawful calling; to pursue any livelihood or avocation and for that purpose to enter into all contracts which may be proper, necessary and essential to his carrying out to a successful conclusion . . . [this purpose]." Allgeyer v. Louisiana, 165 U.S. 578, 589 (1897). Dent v. West Virgima, 129 U.S. 114 (1888), as we have seen, strongly asserted this "right."

79 Occasionally a defendant criminally accused of practicing without a license might not be "reputable" and yet appeal his conviction using constitutional grounds. 
The Wisconsin veterinary medicine law was typical. It required graduation from a "legally incorporated school or college of veterinary medicine and surgery" or a "certificate of qualification as a veterinary physician and surgeon from a legally incorporated veterinary society," but an affidavit of five years contmuous practice was enough to qualify veterinarians in business at the time the act was passed. ${ }^{80}$ For many occupational licensing laws, then, there existed no natural groups of opponents to the statute from whom a challenge was hikely to come. For some laws, opposition was a sign that the statute-wittingly or unwittingly-encroached on the economic territory of another group of "professionals" or a subsegment of the licensed occupation, or attempted to seize economic territory from businessmen with different training and career patterns.

\section{A. Class Warfare and the Undertakers}

The judicial history of the "undertaker-embalmer laws" illustrates the relative scarcity of constitutional challenge and the problem of occupational encroachment.

Licensing was the norm for this occupation by 1900, but hardly a whisper of constitutional conflict was heard in appellate courts. By 1910 only two cases of major significance had been decided. In Wyeth $v$. Thomas $^{81}$ the petitioner, Benjamin Wyeth, had been an undertaker for 46 years. He was the sexton of the First Church of Cambridge. The Massachusetts "board of registration in embalming" promulgated a rule restricting the practice of undertaking to licensed embalmers. Wyeth was not an embalmer and therefore could not qualify for a license. The court admitted that the power of the state extended to control over the burial of the dead. But the court saw no good reason to require all undertakers to be embalmers. A statute so directing would be of dubious constitutionality. Here the board had taken action "under mere general authority to make rules and regulations." Such action did "not carry with it . . . strong presumptions of constitutionality."

More pointed was People v. Ringe $e^{82}$ where the statute (passed in 1905) required all undertakers to be duly licensed embalmers. The New York Court of Appeals made clear that the state had constitutional power to license embalmers and undertakers. But the statute went too far by insisting that these two jobs must be combined in one person. It was common knowledge that undertakers had not always been embalmers and that most rural undertakers were not enbalmers at the time the case

80 Wis. Rev. Stats. 1898, \& 1492f.

81200 Mass. 474, 86 N.E. 925 (1909). In Commonwealth v. Hanley, 15 Pa. Super. 271 (1900), the court sustained the Pennsylvania law, chiefly as a public lealth measure.

82197 N.Y. 143, 147, 90 N.E. 451, 454 (1910). 
was decided. "We cannot refrain," said the court, "from the thought that the act in question was conceived and promulgated in the interests of those then engaged in the undertaking business, and that the relation which the business bears to the general health, morals and welfare of the state had much less influence upon its originators than the prospective monopoly that could be exercised with the aid of its provisions." 83 The act in question also required three years continuous service as an assistant to a licensed undertaker and required each member of a firm to be a licensed undertaker. These provisions interfered with the "commonlaw right to engage in a lawful business;" the statute was an "unnecessary and unwarrantable interference with constitutional rights."

Judicial opinions are not necessarily close-knit statements of logical principle, but it seems reasonably clear what bothered the court in People v. Ringe. ${ }^{84}$ The statute vested "monopoly" power in an occupational group. It gave that group power to oust other reputable practitioners, and to control in an "unreasonable" way the mode of entry into the practice. In other words, the court viewed the undertaker-embalmers as overstepping the mark; they were assuming excessive group power simply for their own gain, and encroaching on the legitimate rights of others. Something of the same worry nagged at the New York Court of Appeals in People ex rel. Tyroler v. Warden. ${ }^{85}$ This case arose under a statute regulating transportation ticket agents. The statute restricted the sale of tickets to authorized agents of transportation companies, but it allowed such agents to sell tickets of other companies. The statute threatened to put all the independent ticket brokers out of business: ${ }^{86}$

Ticket brokerage as a business has been in existence for many years. It is a matter of common knowledge that at great agencies, such as Cook's and Gaze's, tickets can be purchased over great portion of the transportation routes of the world. ... The traveling public in large numbers have come to make use of the facilities afforded by such agencies, of which there are now very many. And Cook's and Gaze's are among the agencies that must go out of business in this state if this statute can live, unless some transportation company shall deem it wise to clothe them with the authority to act as its agents.

83 Again, in State v. Rice, $115 \mathrm{Md}$. 327, 80 Atl. 1026 (1911), the statute attempted to create a single class of undertaker-embalmers. The undertaker-embalmer controversy continued into the 1920's. See State ex rel. Kempinger v. Whyte, 177 Wis. 541, 188 N.W. 607 (1922).

84197 N.Y. 143, 90 N.E. 451 (1910).

85157 N.Y. 116, 51 N.E. 1006 (1898).

86 George Tyroler, the relator, was himself a ticket broker not connected with any transportation company, and was therefore threatened by the statute with loss of his livelihood. The decision was a close one. In the court of appeals, three of the seven judges dissented. 
Existing unaffiliated ticket brokers were given no choice but to submit to a transportation company or go out of business; nor did the existing brokers have any chance to organize their own group to resist the encroachments authorized by the statute. ${ }^{87}$ Again, the problem was one of "monopoly" and "power," that is, of fair and unfair competition between groups or between an economic group and unaffiliated businessmen.

It is plausible that in both these cases the court was anxious to keep the licensed, state-protected occupation in line. The New York court was undoubtedly aware of the history of its statute on embalmers. The first version (1898) barred unlicensed persons from transacting "the business or practice of embalming of liuman dead bodies within this state." 188 The second version (1905) went beyond this. The funeral directors who were embalmers had secured a monopoly of the embalming practice, and now they souglit to eliminate funeral directors who were not embalmers. The new statute required an embalmer's license for any prospective undertaker. The apprenticeslip requirement was prospective; current undertakers might continue plying their trade, if they already had an embalmers license or if they were "engaged in such business [undertaking] with a licensed embalmer." ${ }^{189}$ It was at this point that the constitutional problems arose because here group clashed with group. At this point the few courts which passed on the question exerted their power to control "monopoly" excess disguised as occupational licensing. Here was the horrid visage of what the courts sometimes called "class legislation"-naked intervention by the state on behalf of one group against another group. ${ }^{90}$ But the court's vision was partial and limited. Associ-

87 In the earlier cases of Burdick v. People, 149 Ill. 600, 36 N.E. 948 (1894), and State v. Corbett, 57 Minn. 345, 59 N.W. 317 (1894), somewhat similar statutes were sustained, but the acts in question were treated as regulations of the transportation companies. In Munson v. City of Colorado Springs, 35 Colo. 506, 84 Pac. 683 (1906), an ordinance licensed railroad ticket brokers. An applicant bad to file with the city "a certificate of membership in some reputable ticket brokers' association." Defendant applied for memberslip in an association, but lie was turned down. He "offered to slow that membersbip in these associations is ... limited in numbers, which limit was reached when he applied." The court held the ordinance beyond the power of the city to enact. It improperly delegated power to a "private ... purely voluntary association," so that "wholly unrestrained," the association could make an "arbitrary determination as to who may ... pursue a business ... which one citizen is as capable of conducting as another." Id. at 511, 84 Pac. 685.

88 N.Y. Laws 1898 , ch. $556, \S 9$, at 1303.

80 N.Y. Laws 1905, ch. 562, § 6-a, at 1268.

${ }^{90} \mathrm{Cf}$. Commonwealth v. Zacharias, $3 \mathrm{~Pa}$. Super. 264 (1897). Zacharias owned three retail drugstores in Philadelphia. He employed "regularly registered pharmacists . . . to whom he paid salaries." He was not licensed and was not a pharmacist at all; naturally Le "did not himself ... put up prescriptions or personally sell the drugs." The statute made a license mandatory for anyone who "shall open or carry on as manager ... any retail drug store." The court did not choose to declare the statute unconstitutional on 
ation legislation had meaning for its sponsors only as it aimed at defining an area of exclusive competence and holding it against all comers. No licensing law was directed only at competitors who would clearly be labeled as quacks or imcompetents by all reasonable men. Quite typically these statutes had sharp economic teeth. But the legal (constitutional) issues were framed in terms prescribed by the liabits and language of constitutional litigation. The cases were argued and analyzed as presenting problems of the limits on the state's power to regulate the general terms of economic hife. In fact, the major issues were the state's power to create occupational monopolies and, that point being in some sense conceded, the exact mandate of the licensed monopolylow far could it go, what weapons could it use, what procedures were incumbent upon it. But only in specific instances wlere the statute was crudely worded or blatantly conceived, and where group clashed with group in an unusually clear-cut conflict, was the court's perception of the issue jolted from its normal line of vision.

The undertakers' statutes also illustrate a quite typical trend of development within occupational groups. The initial licensing law was not enough; it merely vested in established practitioners control of the core activities of the occupation. Once this citadel was secure the economic struggle continued, though often in the form of skirmishes against "unauthorized practice" rather than througl fresh demands for legislation to seize economic territory. Perhaps one example will serve to indicate the zeal with which some professions souglit to extend their area of exclusivity. In People v. Hettiger, ${ }^{91}$ Mrs. Hettiger was arrested for practising medicine without a license. She ran a "massage parlor;" she also used an electric lamp, though "only to warm the body and take the chill off the room." The state had asked for an instruction that "as a matter of law all rubbing of affected parts is practising medicine." The court labeled the proposed instruction absurd. It would make "a barber giving a shampoo ... guilty of practising medicine."

In any event, any medical attempt to assert jurisdiction over rubbing scalps and cutting hair would have failed, because the barbers not only practiced a discrete and traditional trade, they were also a licensed pro-

the grounds that the state lacked power to prohibit the unlicensed from running drug businesses, but the court did find a fatal flaw in the statute. It allowed the widow and legal representatives of a deceased manager-pharmacist to carry on the business without a hicense (and not inerely for purposes of winding up the estate). This was an unreasonable exception and made the statute into "class Iegislation."

91150 IIl. App. 448 (1909). In fairness to the medical profession, one must concede the possibility that in this or similar cases the offensive zeal has to be ascribed not to the professionals but to the narrow-mindedness or literal-mindedness of law enforcement officers and prosecutors. But surely all such cases cannot be blamed on this source. 
fession. Indeed, many trades and subtrades sought licensing in selfdefense against previously licensed occupations which threatened to encroach on their means of livelihood. ${ }^{92}$ Massachusetts in 1907 held that a midwife, a graduate of the "Chicago Midwife Institute" and a woman of admittedly "good character and reputation," was guilty of practicing medicine without a license. ${ }^{93}$ Threats such as this from the medical profession drove osteopaths and chiropractors to besiege state legislatures with whatever political power and persuasion they could muster. The power of licensing boards to determine qualifications enabled the boards to excommunicate occupational schismatics. Unless the schismatics could mobilize enough political force to found their own legalized sect, they were doomed to occupational extinction. ${ }^{94}$ Results of compromise

92 See, e.g., State v. Taylor, 106 Minn. 197, 118 N.W. 1014 (1908) (asking whether a doctor can practice dentistry without a license; the answer was no). Some statutes spelled out the doctor's concurrent jurisdiction over teeth. See, e.g., Mont. Rev. Code 1907, § 1581, defining dentistry and adding that "nothing in this act contained shall be taken to apply to plyysicians who may desire to extract teeth." See also Neb. Laws 1907, ch. 85, at 301, licensing "the practice of Optometry," but exempting "permanently located physicians duly licensed to practice medicine under the laws of this State" and "persons who sell spectacles or eyeglasses on prescription [sic] from any duly quahifed Optometrist or Physician" and "permanently located dealers in spectacles or eye-glasses who neither practice nor profess to practice Optometry."

93 Colnmonwealth v. Porn, 196 Mass. 326, 82 N.E. 31 (1907). Some statutes specifically exempted midwives. See State v. Welch, 129 N.C. 579, 40 S.E. 120 (1901); 2 N.C. Cons. Stats. 1919, § 6622. In some states the midwives were licensed. See, e.g., Wis, Laws 1909, ch. 528 , at 718 , but the weakness of this occupational group is indicated by the fact that licensing was vested in the state board of medical examiners, rather than in a board of midwife examiners. In Louisiana, midwives were under the control of the boards of health, but the "so-called midwife of rural districts and plantation practice" was "not considered as practicing midwifery as a profession" and was exempt. 2 La. Const. \& Rev. Laws (1904), \& 1237. The rural midwife has, in many states at least, passed from the scene, but there are hicensed professions which still face the problem of defining and holding an exclusive jurisdiction without claiming so much territory that their mandate will either be revoked by the public or will degenerate into futility. A profession facing this danger is nursing, and the ingenious solution is the distinction between the "registered" and the "practical" nurse. See, e.g., S. Car. Crv. Code 1912, § 1653: After January 1, 1911, "it shall be unlawful ... to practice ... the calling of a professional nurse in this State for compensation," without registration and examination under the control of the State Board of Medical Examiners; but the act did not apply to "those persons nursing the sick for hire who do not in any way claim or assume to be, or to hold themselves out as registered nurses." Note that even the registered nurses in South Carohina did not yet have their own board.

94 The history of the legal status of homeopaths, allopaths, and nagnetic healers would be an instructive story in its own right. Even the study of the case law reveals little subworlds the average layman never dreaint of. For example, the "subjective mechanical means" (as opposed to "objective" ineans) for measuring "the accommodative and refractive conditions of the eye." Did the subjectivist have the right to a license? The Utah optometry board was in the hands of the objectivists, but the Supreme Court of Utah was less narrowminded. State ex rel. Hallen v. Utah State Board of Examiners in Optometry, 37 Utah 339, 108 Pac. 347 (1910). 
were plainly visible in some licensing statutes, which dodged the problem of internal factions by providing for rule by coahtion governments. Thus, Connecticut provided that the "Connecticut medical society, the Connecticut homeopathic medical society, and the Connecticut eclectic medical society" each had the right to nominate to the state board for the examination of prospective doctors. And the statute further exempted from hcensing "any chiropodist or clairvoyant who does not use in his practice any drugs, nedicines, or poison," not to mention persons using the "massage method, or Swedish movement cure, sun cure, mind cure, magnetic healing, or Christian science." ${ }^{\text {"95 }}$ In other states, however, these battles had to be fought after, not before, the primary licensing law was enacted.

\section{B. Horseshoers and the Concept of the Common Vocation}

The difficulties of the horseshoers have already been alluded to. Bessette v. People" in 1901 struck down an Illinois law "To Insure the Better Education of Practitioners of Horseshoeing, and to Regulate the Practice of Horseshoers in the State of Illmois." The law had been enacted in 1897. It set up a board of five examiners-four practicing horseshoers and a veterinary surgeon; an examination and four years' experience were prescribed as prerequisites for a license. The Illinois court found the law objectionable on a number of grounds. Cities of more than 50,000 population were subject to the law, cities of less than 10,000 population were exempt, while cities in the middle range might adopt the law by local option if they wished. The court saw no rational basis for these population distinctions. But the major defect of the law was that, in the court's view, it was "impossible to conceive" how the law promoted the "health, comfort, safety, or welfare of society." And without a relationship to these social aims, no law "regulating any trade, calling, or occupation" could be sustained. The court said: "If this act is valid, then the legislature of the state can regulate almost any employment of the citizen by the requirement of previous study, and previous examination, and the payment of a hcense fee, and the issuance of a hicense."

The draftsmen of the statute were aware of the constitutional problem. They attempted to lay some basis for the argument that the law was connected with liealth, the health of horses, at any rate. A veterinary surgeon was put on the board-carefully insulated by the presence of

05 Conn. Gen. Stat. 1902, $\$ \S 4714,4716$, at 1127. California has long bcensed "drugless practitioners" who do not use medicine and who treat diseases "without in any manner severing or penetrating any of the tissues of human beings except the severing of the umbilical cord." CaL. Bus \& Prof. Code \& 2394.

96193 III. 334, 62 N.E. 215 (1901). 
four horseshoers-and apprentices were required to attend a series of lectures on the anatomy of horses' feet. The court must have looked upon these provisions as mere window-dressing; the opinion made no mention of the veterinary or the lectures. A New York case, People v. Beattie, ${ }^{97}$ filled in the gap. Among other things the court faced the question whether the health of animals was a proper subject of legislation. It was clear that legislatures might prohibit cruelty to animals. But bad horseshoeing at worst might produce an occasional corn, or a pam or two. "The same thing is true in the shoeing of human beings." On the broader question, the court pointed out that customary judicial definitions of the police power were in terms of public health, safety and welfare. "This language is used in respect of persons." Presumably, the horse was excluded.

All in all, however, Bessette and the other horseshoer cases asserted the position that the states had no power to regulate common vocations through licensing. The pohice power of the state extended to regulation of occupations which concerned public health, coinfort, safety or welfare, but a common vocation was not to be hicensed whether it affected a legitimate area of pubhic concern or not. Not that the horseshoer cases asserted this proposition as a rule: Bessette and its followers did not, and could not, stand for a rule so broad. But these cases did establish a clear, if narrow, line of authority holding that the state could not license its resident horseshoers..$^{98}$ The hicensing of "common vocations," of which horseshoers were a major example, was not constitutional. The individual's freedom to contract as a horsesloer or with a horseshoer could not be abridged.

There are scraps of authority in other licensing cases which also stressed the common vocation notion. But the notion was not carried very far by the courts. For example, the results of the cases arising under the barber laws were in marked contrast to the horseshoer cases. Starting about 1900, this line of cases almost uniformly sustained the barber statutes against attack. ${ }^{99}$ Typically, the decisions rested on the state's

9796 App. Div. 383, 89 N.Y. Supp. 193 (1904).

88 See In Re Aubry, 36 Wash. 308, 78 Pac. 900 (1904); People v. Beattie, supra note 97. See also Ex parte Diehl, 8 Cal. App. 51, 96 Pac. 98 (1908), where an ordinance "licensed" horseshoers for revenue purposes; the court conceded that the case law precluded any regulatory licensing of this occupation.

99 State v. Zeno, 79 Minn. 80, 81 N.W. 748 (1900); Ex parte Lucas, 160 Mo. 218, 61 S.W. 218 (1901); State v. Briggs, 45 Ore. 366, 77 Pac. 750 (1904); State v. Armeno, 29 R.I. 431, 72 Atl. 216 (1909); State v. Walker, 48 Wash. 8, 92 Pac. 775 (1907); State v. Sharpless, 31 Wash. 191, 71 Pac. 737 (1903). See generally, Fellman, A Case Study in Administrative Law-The Regulation of Barbers, 26 WASH. U.L.Q. 213 (1941). State v. Walker, supra, held unreasonable that part of the Washington act which required a two-year apprenticeship. Then there were cases such as Wass v. Michigan Bd. of Examiners for Barbers, 123 Mich. 
police power, in particular, the power to regulate occupations connected with matters of public health. The Washington Supreme Court, which had nullified a horseshoer statute in a crisp per curiam opinion, ${ }^{100}$ sustained a barber law in 1907, pointing out that a barber operates "directly on the person."101 The Minnesota Court, in 1900, said that the "health of the citizen" fully justified the law; people needed "protection from diseases spread from barber shops" run by "unclean and incompetent barbers." 102

An occasional protesting voice made itself heard. Rudkin, a Washington judge, irately dissenting, pointedly asked wliy the court slould "declare blindly that the public liealth is involved when all the rest of mankind know [s] full well that the control of the barber business by the board and its licensees is the sole end in view?"103 A direct answer to this sharp question is hard to find if we recall the fate of the horseshoer statutes. The forces which lay behind the inovement to license horseshoers were much the same as those whicli gave rise to the movement to license the barbers. Socially and economically, the two occupations were very similar, and in both cases, the occupation had some connection with issues of health. Barbers touched people's skin and therefore shared a little of the reflected constitutional glory of the doctor. The horseshoer's physical contact with liorses gave him a plausible argument, ${ }^{104}$ but the court confined "public health" to liunians. Yet, the veterinarians achieved licensing easily and met with almost no constitutional challenge. ${ }^{105}$ It was undoubtedly true that sanitary conditions in barber shops were deplorable at the turn of the century. But they could hardly have been more deplorable than conditions in New York's bakeshops. In Lochner, the Supreme Court refused to validate a statute which restricted "liberty of contract" even thougli parts of the statute pursued

544, 82 N.W. 234 (1900), which decided questions under barber statutes without considering the issue of constitutionality.

100 In re Aubry, 36 Wasl. 308, 78 Pac. 900 (1904).

101 State v. Walker, 48 Wash. 8, 92 Pac. 775 (1907).

102 State v. Zeno, 79 Minn. 80, 81 N.W. 748 (1900).

103 State v. Walker, 48 Wash. 8,92 Pac. 775 (1907).

104 See Russ, Many Tradesmen Required to Procure Licenses Before Practicing Their Craft, 69 AIB. L.J. 280 (1907), on the hicensing of liorsesboers: "Any owner of borseflesh well knows the value of this sort of legislation. Perhaps there are many horsemen who have had their horses ruined by the poor shoeing done by incompetent horseshoers."

105 The right to license veterinarians was "conceded" in Ex parte Barnes, 83 Neb. 443, 119 N.W. 662 (1909), and cases arose under the statutes without any discussion of the basic constitutional issue. See, e.g., Wise v. State Veterinary Bd., 138 Mich. 428, 101 N.W. 562 (1904). However, in Ritter v. Rogers, $8 \mathrm{~Pa}$. County Ct. 451 (Northampton Cty. 1906), a judge in Northampton County, Pennsylvania, leeld unconstitutional a portion of the state statute requiring practicing veterinary surgeons without degrees to register within six months or lose their right to practice. 
legitimate aims of public health through legitimate means. The barber statutes, however, were swallowed whole. No sustained attempt was made to separate health regulation from anticompetitive provisions. ${ }^{106}$ Once again, the dominant impression we receive from the legal treatment of association legislation is inconsistency-or at best a multiplicity of standards.

\section{The Licensing of Plumbers: Confusion Compounded}

Considerable litigation followed in the wake of statutes licensing plumbers. These statutes met various fates. In Washington, State ex rel. Richey v. Smith, ${ }^{107}$ in 1906, declared the local statute unconstitutional in an empassioned opinion written by Justice Rudkin:

We cannot close our eyes to the fact that legislation of this kind is on the increase. Like begets like, and every legislative session brings forth some new act in the interest of some new trade or occupation. The doctor, the lawyer, the druggist, the dentist, the barber, the horseshoer, and the plumber have already received favorable consideration at the hands of our Legislature, and the end is not yet, for the nurse and the undertaker are knocking at the door. ${ }^{108}$

Concern for the "public health" was no excuse for the statute. Since man's whole environment influences his health, one might plausibly add the "architect, the carpenter, the tailor, the shoemaker, [and] those who produce and prepare our food," to the "ever-growing list" of the licensed. In fact, "control of the plumbing business by the board and its licensees" was the true aim of the statute. That this, rather than the public health, was the true motive for the law was shown by the board's composition; it consisted only of plumbers, who were thereby "constituted the guardians of the public health and welfare." The act was an "interference with the liberty of the citizen ... in direct conflict with the constitution."

This was a strong statement. Yet the Washington court had approved the licensing of barbers and would continue to do so. ${ }^{108}$ And though all the world, according to Rudkin, knew what selfish motives underlay the plumbers' law, the Maryland Court of Appeals, in 1890, either did not know or did not care to know. An act of 1886 had provided that no person might engage in the business of plumbing in Baltimore without a certificate of competency from the State Board of Commissioners of Practical Plumbing. The Maryland court found good analogies in statutes licensing lawyers, doctors, and druggists. The business and trade of a

106 Something of a distinction was drawn in State v. Walker, 48 Wash. 8, 92 Pac. 775 (1907), but this case is an exception.

10742 Wash. 237, 84 Pac. 851 (1906).

$108 \mathrm{Id}$. at 248,84 Pac. at $85 \mathbf{5}$.

109 See cases cited note 99 supra. 
plumber required "a certain degree of training" to qualify one as a "competent and skillful workman." "We all know that in a large city like Baltimore, with its extensive system of drainage and sewerage, the public health largely depends upon the proper and efficient manner in which the plumbing work is executed." 110 In 1895, the New York court, by a narrow four to three margin, sustained a law licensing master or employing plumbers. ${ }^{111}$ The statute set up a five man board of plumbing examiners, two master plumbers with at least ten years' experience in the business, one journeyman plumber of like experience, a representative of the board of health, and the "clief engineer having cliarge of the sewers." Nechamcus, a master pumber, complained that he was unable to get a license because of his "race and religion," and because he did not belong "to an association of master plumbers." Judge Gray, speaking for the majority, found the law fully justified by considerations of public liealth. True, the statute miglit operate to limit the number of master plumbers, but that was a stroke of "great wisdom," not of "monopoly." "As well might it be said that to compel physicians, or druggists, to take out licenses, is a provision giving a monopoly." The future Mr. Justice Peckham, dissenting, called the act "vicious in its purpose;" it "tends directly to the creation and fostermg of a monopoly." It was a pity that as judges "we shut our eyes to the evident purpose of the statute, and ... impute a purpose to the legislature which it plainly did not lave." The law "detracts from the liberty of the citizen acting as a tradesman in his efforts to support himself and his family by the honest practice of a useful trade."112

In retrospect, few would disagree with Peckham that the "evident purpose of the statute" was as he read it; but nonetheless, American courts, particularly after 1900, were distinctly inchined to uphold laws licensing plumbers. ${ }^{113}$ It was almost universal to approve of licensing in principle. Some cases took a kind of middle ground. Plumbing laws were voided in whole or in part, but for reasons which did not foreclose the possibility of passing a valid act. Thus, Ohio and Wisconsin, in 1898, declared particular plumber laws unconstitutional, but both courts conceded that bad sewage systems were dangerous to the public, a fact which fully justified a well-drawn licensing act. The statutes re-

110 Singer v. Maryland, 72 Md. 464, 19 Atl. 1044 (1890).

111 People ex rel. Nechamcus v. Warden, 144 N.Y. 529, 39 N.E. 686 (1895).

112 Id. at 543,39 N.E. at 691.

113 Plumbers' acts were sustained in Missouri, Ex parte Smith, 231 Mo. 111, 132 S.W. 607 (1910); in Illinois, Douglas v. People ex rel. Ruddy, 225 III. 536, 80 N.E. 341 (1907); Caven v. Coleman, 96 S.W. 774 (Tex. Civ. App. 1906) upheld a Texas act quite similar in its critical features to the Wisconsin act struck down in Winkler v. Benzenberg, 101 Wis. 172, 76 N.W. 345 (1898). 
viewed, however, permitted a firm to qualify all its employees by procuring a single license. This was objectionable. ${ }^{114}$ Similarly, one lower court in Pennsylvania struck down, as an improper delegation of authority, a law which authorized certain local boards of health "to adopt and promulgate ... rules ... for the registration of journeyman and master plumbers and persons engaged in plumbing business." Yet the court said, "we believe fully in the wisdom and propriety of laws controlling and regulating sanitary plumbing and do not want to be considered as throwing anything in the way of proper regulation of such subject matters." passage of new acts, and indeed frequently suggested what statutory provisions would be legally acceptable. On the other hand, each such decision did wipe a hicensing statute off the books, and some courts which approved of hicensing "in principle," must have actually deemed such statutes to be of doubtful wisdom, hence liable to be scrutinized more carefully than others.

In Schnaier v. Navarre Hotel \& Importation Company, ${ }^{110}$ in 1905, New York took a fresh look at the hicensing of plumbers. The statute required all members of any New York city plumbing business to be "registered." Registration in turn depended on a "certificate of competency from the examiming board of plumbers of the city." In Schnaier, only one member of a two member firn was registered. This man "attended to the plumbing work;" the other member "was the financial man, and was not registered, and could not be registered, since he was not a plumber." The statute, according to the court, infringed on the "natural rights" of the residents of the state. Laws which "limit one in his choice of a trade or profession" are "infringements" upon a "fundamental" right. "The common business and callings of life, the

114 See State v. Gardner, 58 Ohio St. 599, 51 N.E. 136 (1898); State ex rel. Winkler v. Benzenberg, supra note 113 .

115 Commonwealth v. Shafer, 32 Pa. County Ct. 433, 54 Pitts. 71, 10 North 292, 20 York 73, 2 Leh. 74 (Clearfield Cnty., Pa., 1906). But see Commonwealth v. Lambrecht, 3 Pa. County Ct. 323 (1887). Another plumbers' statute came before the Pennsylvania Supreme Court in 1905, and was sustained in a crisp per curiam opimion. Beltz v. City of Pittsburg, 211 Pa. 561, 61 Atl. 78 (1905). In State ex rel. Chapel v. Justus, 90 Minn. 474, 97 N.W. 124 (1903), a Minnesota law which apphed only to journeymen plumbers in "any city or town with a population of ten thousand or more" was labeled "special legislation" by the court and struck down. The act had two vices-the distinction between journeymen and masters, and the limitation to large cities. "The effect of imperfect plumbing is as pernicious .... in a village or town without a sewer or water system as where such public works exist." By implication, a law which was "general" would be constitutional.

116182 N.Y. 83, 74 N.E. 561 (1905). The problem of a partnership between a bicensed plumber and an unlicensed associate was litigated in Jennings v. Chute, 74 N.Y. Supp. 739,37 Misc. Rep. 39 (1902), but the constitutional issue was not raised. See also Johnson v. Dahlgren, 52 N.Y. Supp. 555, 31 App. Div. 204 (1898). 
ordinary trades and pursuits, which are innocent in themselves ... must ... be free in this country to all alike, upon the same terms." The problem in Schnaier resembled that of the second wave of undertaker statutes. The statute extended the licensed plumbers' monopoly over the business as well as over the practice of plumbing. This heightened the court's sensitivity to constitutional limitations and sent it groping for a rationale. The language of the case stressed that plumbing was a common vocation. Yet the earlier New York plumbers' case stressed the plumbers' great "skill;" his work needed "supervision;" it was performed "in places which are dark, or inore or less inaccessible."117

The plumbing cases, unlike the horseshoeing cases, seem delicately balanced. Normally, American courts sustained the laws, stressing their connection with public health, and the professionalism ("skill") of the plumbers. But where the particular statute had some unusually objectionable feature, where, for example, it encroached on the rights of other groups or unaffiliated but reputable businessmen, the balance was tipped. The element of "monopoly" was perhaps the determining factor, but the courts preferred to speak the language of common vocation.

The "monopoly" rationale, rather than the "common vocation" rationale, fits State v. Brown. ${ }^{118}$ Here a Washington statute defined the practice of dentistry so as to require anyone who miglit own, run, or manage a dental office" to be licensed. Dentists were certainly "professional," yet the statute was voided. Again, in Noel v. People,,$^{119}$ in 1900, an Illinois phannacy law was leeld unconstitutional insofar as it authorized the pharmacy board to license sellers of proprietary medicines and to require all such sellers to be registered pharmacists or to employ registered pharmacists. The statute created an unlawful "monopoly."120 Judicial perception of "monopoly" was connected, however, with judicial

117 People ex rel. Nechamcus v. Warden, 144 N.Y. 529, 537, 39 N.E. 686 (1895).

11837 Wash. 106, 79 Pac. 638 (1905).

118187 IIl. 587, 58 N.E. 616 (1900).

120 Even in this case the court conceded that the state could legitimately control, through licenses, the selling and compounding of drugs other than proprietary, packaged remedies. The pharmacists, of course, were interested in controlling the retailing of drugs of all kinds. Their 1900 model law (A General Form of Pharmacy Law as Amended and Approved by the American Pharmaceutical Association at Richmond, Virginia, May 1900) proposed making it unlawful "for any person not licensed as a pharmacist ... to own, conduct, or manage any pharmacy, drug or chemical store, apothecary shop, or other place of business for the retailing, compounding or dispensing of any drugs, chemicals or poisons." Statutes embodying this concept were adopted in some jurisdictions. See, e.g., Kirby's Dig. Ark. Stats. 1907, \& 5273. In other states, the pharmacy law specifically provided otherwise; see e.g., 2 Howell's Mich. Stats. Ann. 1913, § 5156: "[Act] . . . shall not be construed as precluding any person from owning a drug store or pharmacy if all of the pharmaceutical work in the same shall be under the personal supervision and direction of a registered pharmacist." 
perception of the professional status of particular occupations. The court could not see why licensed druggists must control the business of selling drugs; yet courts would brook no formal, financial control over the business of practicing law or medicine. Hence the prohibition on the corporate practice of these old-line professions. "The bar . . . would be degraded if even its humblest member became subject to the orders of a moneymaking corporation . . . ."121 Lawyers and doctors have both insisted on the necessity of preserving the "sacred" personal relationship between practitioner and client. But corporate practice endangered the individual practitioner perhaps more than it endangered his client. Corporate practice raised the possibility of large-scale, efficient organization. The injury to the established group of practitioners was potentially as harmful as the danger to small retailers from chain store operations. Doctors and lawyers, unlike small retailers, had considerable success in preserving the essential social and economic configurations of their professions, as they existed in 1900. Control over professional education and over socialization and admission to practice were powerful factors in this success; licensing played and plays an important role in the system of control. But the success of licensing laws depends upon the absence of organized economic adversaries and upon the ability of the profession to mount persuasive arguments (both in the legislature and in the courts) on the legitimacy of licensing. The licensing of barbers and undertakers has also been a success in the long run for these occupations, though for both groups the absence of innovations in technology, marketing, and distribution must share in the credit. Chain stores have made great inroads into the business domain of the licensed druggists, who have, however, maintained strategic control over the supply of key personnel. The domam of hicensing has been, since 1910, vastly extended to a whole host of new "professions." The clear economic, social, and status gains of licensing have been attractive to many occupations, while for others the encroachment of licensed groups has made licensing a vital weapon of self-defense. For many occupations, the legislative struggle is still intense, but the judicial struggle has considerably abated. As we saw, even at the turn of the century, the courts did not strenuously resist that form of association legislation we call friendly licensing; and such resistance as there was, was weak and usually ineffective. The horseshoers were a notable exception. ${ }^{122}$

121 In re Co-operative Law Co., 198 N.Y. 479, 92 N.E. 15, 16 (1910). On the prohibition of corporate practice of medicine, see People v. John H. Woodbury Dermatological Institute, 192 N.Y. 454, 85 N.E. 697 (1908).

122 The hapless modern analogues of the horseshoers are the commercial photographers; photography is "one of the many usual legitimate and innocuous vocations by which men 


\section{IV}

\section{JUDICIAL CONTROL OF LICENSING: SOME THEORIES}

It is now time to return to the original question, and ask what the evidence of the occupational licensing cases indicates about judicial behavior in matters of "liberty of contract" in the period from 1890 to 1910.

We are in search of a general theory. To some extent each jurisdiction behaved in a manner peculiar to itself. The Supreme Court of Illinois, for example, was notorious for its ardor in developing constitutional doctrine to cut down state statutes. ${ }^{123}$ Individual opinionated judges, whose influence must be taken into account, stand out from the mass of decision makers. The most Lochner-like decisions in Illinois bore the signature of Benjamin Drake Magruder. ${ }^{124}$ In Washington state, Frank Rudkin registered extreme opposition to licensing laws, and Rufus Peckham ${ }^{125}$ carried his faith in "liberty of contract" from New York to the United States Supreme Court. Yet such influence had its limits. Some of the most ringing affirmations of laissez-faire appeared in dissent.

One conclusion is obvious; neither the United States Supreme Court nor the state supreme courts as a whole ever judged social legislation on the basis of any consistent pattern of ideas wlich can properly bear the name of an economic theory.

earn their daily bread. It is, in essence, a private business unaffected in a legal sense with any public interest." So saying, the North Carolina Supreme Court cast down a statute setting up a "State Board of Photographic Examiners," and joined a large number of jurisdictions which had done likewise. See State v. Ballance, 229 N.C. 764, 51 S.E.2d 731, 735 (1949). A similar group is the watchmakers. See State ex rel. Whetsel v. Wood, 207 Okla. 193, 248 P.2d 612 (1952). Even though all the reported cases thus far have gone against the licensing of watchmakers, Minnesota still licenses them, under a statute passed in 1943, Minn. Laws 1943, ch. 474, at 639, and still on the books. See Minv. Stat. ANn. \& 326.54 (Supp. 1964). One "profession," the ministry, remains outside the licensing laws, and necessarily so, because of the "wall" between church and state. Within particular religions, effective controls over education, socialization, and ordination sufficiently substitute for state licensing. Because of their internal cohesiveness, religious denominations can force the "unlicensed" to desist, conform or leave. The nonconformist, however, can found his own religious group. Thus absence of licensing makes itself felt in the proliferation of American sects. To a limited degree, the same thing is true of the medical profession-orthodox medicine las never been entirely successful in insisting on one established medical church and burning all osteopathic and chiropractic doctors (not to speak of Christian Science practitioners) at the stake. Since there is no constitutional doctrine of the separation of medicine and state, the result has been in many jurisdictions the creation by law of a closed number of "established" medical churches. See notes 94 and 94 supra. Interestingly enough, a distinct medical ecumenical movement has set in in recent years.

123 Matheny, The Judicial Annulling of Statutes, Proc. Itz. Bar Ass's, 32ND ANN. Meeting, Pt. II, 14 (1908).

124 On Magruder, see Proc. Itr. St. Bar Ass'N 226-27 (1910); 35 Rep. AMr. Bar Ass'N 668-70 (1910).

125 See 14 Dictionary of AMIERICAN BIOgraphy 385. 
The associational, anti-competitive urge of occupational groups in the late nineteenth and early twentieth century took various forms, which had various characteristics in common. The judicial response to legislation, however, did not seem to derive from an uncluttered judgment of the effect on competition and free enterprise of the association activity legitimized by the statute reviewed. Sometimes the court looked to the effect on competition and freedom of contract, as in Lochner and Bessette. Sometimes, as in the barber cases, it did not. The cases as a whole cannot be explained as consistent applications of a laissez-faire ideology mixed with a consistent philosophy of judicial power to assert that ideology in the course of judicial review. The theory expressed by Holmes in his Lochner dissent cannot explam all the association legislation cases of 1890 to 1910, and perhaps it cannot even explain Lochner. The courts, including the United States Supreme Court, were friendly to many aspects of association legislation, occupational hicensing, Sunday Laws, even some purely "labor" laws, and unfriendly to others. ${ }^{126}$ No consistent ideological pattern emerges from the case law.

Some critics have seen in the work of the judiciary not ideology but simply bias. A left-wing Wisconsin labor leader called the courts "capitalistic annexes"; ${ }^{127}$ in his view, courts consistently acted to favor the propertied classes, or to hamper organized labor. The Debs case, ${ }^{128}$ the Income Tax case, ${ }^{129}$ Lochner and other anti-labor cases, and the cases which narrowly construed the Sherman $\mathrm{Act}^{130}$ all lent credence to this point of view. There is no doubt that many courts were, in attitude and behavior, far to the right of labor leaders and reformers of the day, and some individual judges were egregiously so. Yet the same judges who were, in some instances, so quick to see through the police power rationalizations of "labor" legislation, were perfectly willing in other cases to blind themselves. This tendency appears in almost all of the courts. It is confirmed by the vacillation in the occupational licensing cases. The

126 The Supreme Court itself, in Petit v. Minnesota, 177 U.S. 164 (1900), upheld a barbers' Sunday closing law, and in Holden v. Hardy, 169 U.S. 366 (1898), the Court upheld an eight-hour law for miners on health grounds. Peckham was at great pains to distinguish this case in Lochner, somewhat half-heartedly, one imagines, since Peckham dissented in Holden.

127 Fred Brockhausen, Secretary-Treasurer of the Wisconsin State Federation of Labor, in 13 Proc. Ann. Convention Wis. State Federation of Labor 39 (1905).

${ }^{128}$ In re Debs, 158 U.S. 564 (1895). A concise discussion of the background of this decision is in Paul, Conservative Crisis and the Rule of Law 131-58 (1960).

129 See note 11 supra.

${ }^{130}$ See, e.g., United States v. E. C. Knight Co., 156 U.S. I (1895). This case arose out of the acquisition by the American Sugar Refining Co. of all but one of its remaining competitors. The majority of the court felt that the Sherman Act did not apply because sugar refining was "manufacturing" and not "commerce"; the Sherman Act covered only restraints upon commerce and trade. 
difference between the legislative fate of the horseshoers and the barbers is a minor but striking instance. And protective labor legislation was generally sustained by the United States Supreme Court and inost state courts, though with flagrant exceptions.

A more moderate and plausible" description of the judicial temperament or bias of the day is middle-class. Friendly licensing was a middleclass plienomenon by and large. It aided the "professions" and those groups of artisans and white-collar workers who were striving for middleclass or professional status. The middle-class mentality, one might argue, viewed with distaste only those aspects of the associational impulse which it could not assimilate into its own value system. It could not readily understand the aspirations of masses of landless, urban workers, many of them foreign born and politically radical. It shrank in horror from the violence and threatened violence of what it saw as class warfare in an industrial setting. It tended to blaine organized labor for the use of such tactics as strikes and boycotts. Nor, on the other hand, was the middleclass mind particularly open to the aspirations of the business upper class, to the industrial giants, the "trusts," and the railroad oligarchs. These plutocrats seemed to threaten to enslave the country. Moreover, their wealth and power undermined the prestige of the old-hine occupations (including judges and lawyers) and threatened the stability of a social system thought to rest on older, less materialistic Aunerican ideals. ${ }^{131}$

It must surely be true that the attitudes of their social and economic class powerfully influenced the work of the judges. But a general class explanation does not explain, for example, soine of the hair-line decisions made in constitutional cases-for example, decisions turning on the reasonableness of classification, or on the correctness of the title of a bill passed by the legislature. The occupational hicensing cases show many instances of judicial decisions which approved hicensing for a particular occupation in principle but rejected the licensing statute on specific grounds or with regard to some specific feature. Many of these cases were reactions against "class" legislation, in the sense of encroachment of one group upon another equally reputable group. If a court disapproved as discriminatory a statute licensing doctors, ${ }^{132}$ the court's rea-

131 See Hofstadter, The AGe of Reform (1955).

132 A New Hampshire statute licensed physicians and dentists, except that practitioners who had "resided and practiced their profession in the town of their present residence ... since January 1, 1875" were partially exempt. The New Hampshire Supreme Court struck down this provision. The court found odious the discrimination between doctors and dentists who stayed put, and those who did not. The discrimination, however, was in keeping with the general tendency of association-legislation to favor established practitioners over the less established or non-established. But it is extremely unlikely that the court wanted no licensing statute and was merely deciding the case on the least sweeping grounds available. 
soning can be taken seriously; there was general legal consensus on the principle that the state had power to license its doctors and, indeed, that it ought to. ${ }^{133}$ Decisions against group encroachment merged imperceptibly into others apparently based on general, imperfectly articulated notions of "fairness," or on grounds which owe some of their force to the persuasive analogical powers of formal legal arguments. Judges rationalize, but they are not to be accused of hypocrisy, bias or dogmatism in every judicial decision. ${ }^{134}$ They operate within the law, that is, they are swayed to a greater or less extent by elements of the legal tradition itself - what Roscoe Pound called the "taught tradition."

Pound himself, in his 1909 article on "Liberty on Contract,"135 a scathing indictment of the courts, pointed the finger of blame at legal habit and tradition. Pound, lowever, also recognized the power of the "individualist conception of justice, which exaggerates private right at the expense of public right, and is hostile to legislation, taking a minimum of law-making to be the ideal."136 In Pound's opinion, the judges were guilty of using "mechanistic jurisprudence," in wlich "conceptions are developed logically at the expense of practical results and in which the artificiality characteristic of legal reasoning is exaggerated." Antiquated notions of the state and "eighteenth century pliilosophy of law" survived to plague twentieth century man, apparently because these older mental habits became encysted in the minds of judges and lawyers, through training and professional socialization.

Undoubtedly, the legal tradition nust be added to the cluster of factors explaining the association cases. The force of purely legal ideas (and non-legal ideas engrafted onto the legal tradition) undoubtedly operated to influence the work of the judiciary, though unfortunately in ways difficult to measure. Yet Pound's position has its own difficulties. It is somewhat inconsistent to accuse judges of antiquated notions, and then indict them for applying these notions in a novel manner to strike down popular legislation. It is odd to mention the legal tradition and the eighteenth century in the same breath as the post-Civil War amendments and the newly-developed constitutional concept of liberty of contract. The development of substantive due process was a bold example of legal innovation, even though the result of legal innovation was economic conservatism.

Courts in general clearly prefer to use legal rhetoric and follow legal

133 See authority note 30 supra.

134 See, for a forceful exposition of this view, Mendelson, The Neo-Behavioral Approach to the Judicial Process: A Critique, 57 AMr. Por. SCr. REv. 593 (1963).

13518 YaLE L.J. 454 (1909).

136 Id. at 457 . 
habits of thought. The claim of judges to professional status depends in part upon knowledge and use of a specialized body of knowledge and a specialized trade language. Furthermore, logical consistency is not characteristic of Anglo-American judge-made law. It is and was a common phenomenon for two dissonant lines of authority on a particular point to coexist. Some accident of analogy or judicial temper gives rise to competing lines, and each line is then propelled forward in time by the force of precedent and persuasion.

Probably, these dissonant lines of authority exist mainly where competing analogies liave enough overlap and difference to blur the criteria of choice between them. The barber cases and the lorseshoer cases may represent two such competing lines. The horseshoer statutes were called into question in states, such as Illinois, where freedom of contract dogma was relatively persuasive with the court. The public lealth analogy was weak, compared to its force in the barber cases, and the statutes fell, even though the same jurisdictions accepted paternal regulation of barbers. These courts did not necessarily believe that the barber laws were purely liealth laws. It is enough that the liealth argument was persuasive. Added to other judicial doctrines, including the presumption of constitutionality, lealth arguments operated to enlist wavering judges on the side of constitutionality. In the legislature, plausible health arguinents liad the same effect, and inoreover helped to enlist "middle-class" reformers in support of proposed associational legislation, or at least to neutralize dogmatic opposition. There was an easy and direct line of legislation and case law leading from doctors to dentists to barbers. This lime had to be pushed a bit harder to reach plumbers, while the lorseshoers became trapped in the coils of another line leading elsewhere.

The strength of familiar legal concepts probably had a good deal of impact on the fate of other types of associational legislation. Wage and hour legislation was most successful when applied to the labor of women and children. Mimors and married women lacked complete contractual capacity at common law, and thus it could hardly be asserted that control of their contracts by the legislature infringed on natural, unqualified rights. Though liumanitarian, economic, and pohtical considerations were all-important factors in the passage of child labor acts, the traditional legal position of minor children lelped disarm constitutional arguments of extreme conservatives.

Other labor laws and social legislation followed the line of least resistance to familiar legal concepts and persuasive analogies of policy, for example, full-crew laws. Wisconsin's 1907 statute required small passenger trains (three cars or less) to carry at least "one engineer, one fireman, one conductor and one brakeman;" larger trains needed 
two brakemen. ${ }^{13 \tau}$ One major aim of this law was to make more jobs for members of the railroad brotherhoods. But the supposed public danger from skimpy railroad crews was a reasonable and hence persuasive argument for validating these laws. Similarly, maximum hours laws for railway labor could be supported by pointing out how dangerous it was if tired trainmen operated passenger trains. "It is easy to see," said Frederic Stimson, "that ... statutes . . . which provide for a necessary rest for railroad employees after long periods of service, are necessary to the public safety."138 The same emphasis on public health and safety which led, among other things, to the food and drug law, lent some of its rletorical force to support these laws whose connection with health and safety was a shiade more remote.

A residue of cases remains in which courts cast down occupational hicensing laws on miscellaneous grounds, grounds seemingly irrelevant to the substantive issues underlying the statute. Some cases held laws void because the laws made "arbitrary" distinctions between big cities and small cities, or contrariwise, because no such distinctions were made. Some courts set aside legislation because of procedural inperfections in the legislative process. For example, Fillmore v. Van Horn, ${ }^{130}$ a Michigan case, voided a barber licensing statute because of a clerical error. The two houses of the legislature liad never agreed to the same title for the bill. The result of the case was simply to leave in effect a prior licensing law which was slated for repeal by the law struck down by the court. The two hicensing laws were not very much different-not different enough to lay the basis for any idea that the court had some ulterior motive for its action (or more accurately, any ulterior motive with respect to the licensing of barbers). There is no point looking in these cases for class bias or economic theory. These decisions were at worst a feeble form of obstruction. They invited re-enactment in a more palatable forın. Cases like Fillmore were devoid of any flavor of economic policy.

One factor, lowever, is cominon to all the cases in which courts overturned occupational licensing laws, and, indeed, to all the cases in which the court exercised its power of judicial review to void economic legislation. This factor is nothing more than the judges' perception of their own power. What underhes these cases is a sense of the right, the power, the duty of judges to pass judgment on legislation and the legislative

137 Wis. Laws 1907 , ch. 402, at 1032 (text p. 494); a more sweeping law was passed in 1913. Wis. Laws 1913, ch. 63, at 70; see 1 Laws N.Y. 1913, ch. 146.

138 Stimson, Handbook to the Labor LaW of the UNited States 70 (1896). An act regulating the hours of labor on street railways was passed in New York as early as 1886. N.Y. Laws 1886, ch. 151. In Wisconsin, see Wis. Laws 1907, ch. 575, at 1188 (text p. 497) (consecutive hours of railroad operators).

130129 Mich. 52, 88 N.W. 69 (1901). 
process and to do so on an unprecedented scale and with unprecedented force. The courts of the period were bold, innovating, active courts. It is the concept of judicial self-restraint which is so conspicuously lacking in the great constitutional cases and in a fair share of the occupational licensing cases as well. When all is said and done, the phenomenon which demands explanation is the activism of the courts of 1890 to 1910 .

Perhaps that activism owed something to the same urge that underlay association legislation: the urge of occupational groups to define and -protect areas of exclusive jurisdiction. No one, it is true, threatened the economic position of the judges. But their power and prestige were threatened. The increasing volume of legislation began to undermine the earlier role of the judges as leading makers of public policy. Codification and enactment undercut the importance of the judge as a creator of living law. Judges reacted by seeking out an area of exclusive competence, just as the barbers did. The power of judicial review over legislation, sparingly used before the Civil War, gave them the doctrine. The enactment of the vague language of the Fourteenth Ainendment gave them the opportunity. Current social concepts, particularly middle-class values and inherited doctrines of law, provided the liniting banks within which the course of judicial power ran. But the urge to claim this area of competence and to hold it against their rivals was, perhaps, no different from the impulse which sent unorganized funeral directors (or barbers) into each others' arms, save that a precise dollars and cents motivation was lacking. Tutored by Langdell and other scholars of like persuasion, the legal profession itself had retreated into a refined and almost mystical deification of the common law as one means among many of supporting the jurisdictional claims of the lawyers over particular areas of human behavior. But the lawyers could and did react in the usual professional pattern, by forming bar associations and through the licensing movement. The lonely, unaffiliated judges, whose career patterns often were elective and precarious, were cut-off from organizational satisfactions and had to react, if at all, through aggrandizing the power of their offices and deifying the nature of their work.

In asserting its claim the judiciary was necessarily driven into a posture which from the standpoint of later generations appears reactionary. Legislatures were from time to time in the hands of populists and progressives. The controversial legislation which came from these assemblies was association legislation of a kind which aroused vigorous opposition within the legislature and in any forum where the struggle might be carried on. Even middle-of-the-road legislatures passed many associational statutes (notably, occupational hicensing laws), and these too aroused challenges in some cases. Sinply to rubber-stainp legislative 
decisions might seem a weak and humiliating role for the judges. The natural form of judicial self-aggrandizement was to assert a frequent, bold power of review over official acts, including legislative acts. But in a time of social ferment and legislative experiments, any judicial activism meant the defeat of association legislation, including some measures of social reform and measures favorable to organized labor. True, the power of review was sporadically asserted. But it was asserted often enough to count - often enough so that any major statute had to run or face the possibility of running the constitutional gamut, often enough so that legislatures, reformers and bill-drafters had to ask themselves: "Is this proposal constitutional?"140

In the mid-twentieth century substantive due process is essentially dead as a weapon of control over economic legislation. It died in the late 1930's in the United States Supreme Court, except for an occasional twitch since then, although sone have sensed at least the possibility of a partial resurrection. ${ }^{141}$ "Liberty of contract" is all but dead as judicial doctrine in the states, although substantive due process retains much more vitality in the states than in the federal courts. ${ }^{142}$ But the decline of substantive due process has not ineant the end of massive federal judicial power. The United States Supreme Court is as bold, as innovating, as controversial today as in the days of Lochner. The Court is, lowever, "liberal" rather than "conservative." It protects and advances liberal ideals-civil rights, civil liberties, freedom of expression, separation of church and state.

The great cases of the age of Lochner also spoke the language of civil liberties. They spoke of the rights of nuan and of the sanctity of

140 According to MOORE, The SUPReme COURT and Unconstituttonat Legislation (1913), the Supreme Court had declared unconstitutional 33 federal and 217 state statutes up to 1910. The peak decade was $1880-1890$ (4 federal, 48 state statutes); the peak percentage of state statutes nullified (compared to all statutes reviewed) was the decade $1860-1870(47 \%)$. In $1900-1910$, only $16 \%$ of the state statutes reviewed were nullified. $I d$. at 140-41. But the number of reviewed statutes was greatest in 1900-1910. These figures, if trustworthy, indicate that the court began strongly to assert its power of review just after the Civil War, and that by 1900 the idea that important state legislation might have to run the constitutional gamut was firmly established. To keep its power mandate fresh, the Supreme Court did not need to continue to void a high percentage of the statutes it reviewed. And unquestionably, statutes were challenged in 1900 that would not have been challenged in an earlier generation.

141 McCloskey, Economic Due Process and the Supreme Court: An Exhumation and Reburial, 1962 SUP. Cr. REV. 34.

142 See generally Hetherington, State Economic Regulation and Substantive Due Process of Law: State Courts, 53 Nw. U.L. REv. 226 (1958). Highly controversial cases-labor, civil rights-have largely passed to the federal courts. The state courts retain low visibility cases of economic regulation-occupational licensing cases are an excellent example. In the absence of strong pressures to abandon judicial review, the state courts continue playing approximately the same role with regard to occupational hicensing as they did in the age of Lochner. 
private property. The courts portrayed themselves as the forum where individual liberty might find shelter against the encroachments of governmental tyranny and caprice. The cumulative effects of depression, war, and social-political change have forced the Court to abandon its power over legislation designed to affect economic behavior. As if by magic, freedom of expression and the rights of ethnic and racial minorities replaced older issues and became the focal point of the Court's new activism. The issues of Lochner, a fortiori of Bessette, are no longer thought of as questions of civil liberties at all. The new, heightened judicial sensitivity to issues of personal freedom is arguably only a redefinition of the essential elements of constitutional hiberty. Perhaps the Court's new role in "civil liberties" matters owes something to its hunger for a share in the universe of political power-something to replace the dead issues of substantive due process. The politics of the post-World War II era do not preclude the Supreme Court from playing a major political role; nor does the institution itself decline to play that role. But necessarily the Court does its boldest work with new issues. To be sure, issues are not invented by the Court, they are thrust upon it. Yet the Court's eager reception of certain types of cases invites more cases. One successful legislative apportionment case or racial segregation case leads to another. The Court's history, training, and self-perception and its tradition of vigor and independence all have suited the Court for a prime role in settling disputes at that juncture point where governmental force is exerted upon individual members of society.

. Both in the period of Lochner and the period of the school segregation cases, ${ }^{143}$ the school-prayer case, ${ }^{144}$ and Baker $v$. Carr, ${ }^{145}$ the bold activism of the Court has been subjected to criticism of all sorts. Much of this criticism is directed at the substance of the Court's decisions; but some critics accuse the Court of upsetting the structure of American government, while admitting that the Court's decisions are otherwise ethically sound. The Court's trouble, they say, is that it has abandoned the application of sound, objective "legal" principles, in favor of ad hoc decision-making based on reactions of the heart and nerve-endings. The remedy is to return to "neutral principles"146 of constitutional law. Interestingly enough, liberals too seem uneasy. And one group, with spokesmen on the Court, is engaged in a search for constitutional absolutes, ${ }^{147}$

143 Brown v. Board of Educ., 347 U.S. 483 (1954).

144 Engel v. Vitale, 370 U.S. 421 (1962).

145369 U.S. 186 (1962).

146 The phrase is due to the now famous article by Professor Wechsler, Toward Nentral Principles in Constitutional Law, 73 HARv. L. REv. I (1959). Something of the same position is articulated by Learned Hand in THE BIII of RIGHTS 50 (1960).

147 Thus, Justice Black: "It is my belief that there are absolutes in our Bill of Rights, and that they were put there on purpose by men who knew what words meant, and meant 
which if discovered and canonized would free the nation and the Court from the danger of ad hoc tampering with fundamental civil rights. But the search for "neutral principles" and for "absolutes" is a search for values that cannot be found and which have never existed. Principled neutrality and absolutism, like all other doctrines of constitutional law, can be nothing more than attitudes, selectively applied, statements of tendencies rather than "rules," tendencies whose areas of application, in any given period, are powerfully influenced by social facts.

The Supreme Court has been praised and blamed for its self-restraint in some areas; in other areas, it has been praised for boldly leading a laggard public opinion and blained for usurpation. The truth of the matter is that the Court cannot exercise self-restraint in every class of constitutional case. If it does so, it loses a major share of its power and importance, and institutions do not readily consign themselves to lesser roles. The fate of the English nonarchy may eventually overtake the Supreme Court, but this does not seem likely at present. The Court enjoys power in both senses of the word "enjoy;" it will long continue to exercise selectively both power and self-restraint. John P. Roche has suggested that "judicial self-restraint and judicial power seem to be opposite sides of the same coin," and that the court acts boldest where political power is most fragmented, retreating into self-restraint where it confronts "monolithic majorities." 148 One might expect the court to exhibit a different mix of restraint and bold creativity in each particular period. Through act and rhetoric, the Supreme Court has vigorously sustained the rights of minorities, and the rights of all citizens to freedom of expression. Partisans of the democratic process and of personal liberty are naturally sympathetic to what the Court is doing. There is no reason to be ashamed that the Court is not "neutral" once one accepts that the Court cannot be "neutral" on questions which call for a definition of key values in society, and if we think the Court is non-neutral in directions which are morally sound and good for the country. Selectivity, inconsistency, and imperfection are not unique characteristics of the Warren Court or any other high court; nor are they simply consequences of personal weaknesses of the judges. They are inescapable consequences of the historical and social process which has molded the Court as a functionimg legal and political institution. In smilar fashion, the Court's docket of men and events is not a matter of accident, and the Court's response to its docket owes more to history than ideology, more to politics than "legal science," more to economic and social facts than to the rhetoric of the moment. 